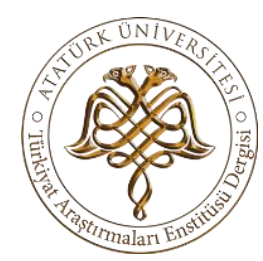

\title{
BURSA CIVARININ İŞGAL VE KURTULUŞ SÜRECINDE ASKERÎ HAREKÂTLAR
}

\author{
MILITARY OPERATIONS IN THE OCCUPATION AND LIBERATION \\ OF BURSA AND ITS VICINITY \\ YÜCEL ÖZTÜRK \\ Dr., Tarih Anabilim Dalı \\ Dr., Department Of History \\ yozturk1526@gmail.com \\ iD https://orcid.org/0000-0001-7540-7030
}

\author{
Türkiyat Araştırmalan Enstitüsü Dergisi - Journal of Turkish Researches Institute \\ TAED-65, Mayıs - May 2019 Erzurum \\ ISSN-1300-9052 \\ Makale Türü-Article Types : Araştırma Makalesi-Research Article \\ Geliş Tarihi-Received Date : 12.09 .2018 \\ Kabul Tarihi-Accepted Date : $\quad 26.04 .2019$ \\ Sayfa-Pages : 381-405 \\ doi : http://dx.doi.org/10.14222/Turkiyat4037

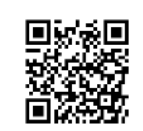 \\ www.turkiyatjournal.com \\ http://dergipark.gov.tr/ataunitaed \\ This article was checked by \\ $\checkmark$ iThenticate
}





\title{
BURSA CIVARININ İŞGAL VE KURTULUŞ SÜRECINDE ASKERÎ HAREKÂTLAR

\author{
MILITARY OPERATIONS IN THE OCCUPATION AND LIBERATION OF \\ BURSA AND ITS VICINITY
}

\author{
YÜCEL ÖZTÜRK
}

\begin{abstract}
Öz
I. Dünya savaşı sonunda imzalanan Mondros Mütarekesi, Bursa için de işgal sürecini başlatmıştır. İşgal güçlerinin ve İstanbul Hükümeti'nin Bursa halkını kendi saflarına çekme yönündeki girişimlerinin, halkın bir kısmı ve şehrin bazı yöneticilerince karşılık bulması, Ankara Hükümeti'nin Bursa ve civarının işgalinde bir süre kesin tavır alamamasına sebep olmuştur. Belirsizlik süreci, Bursa ve civarının savaşılmadan teslim edilip, geri alındığı gibi algılanmalara yol açmıştır. Bu durumun aydınlatılabilmesi için işgal ve kurtuluş sürecinde Marmara bölgesi, İznik, Orhangazi, Gemlik, Mudanya, Bursa ve civarındaki tüm askerî harekâtlar, Anadolu'yu kurtuluşa götüren askerî harekâtlarla birlikte ele alınmıştır. Bursa ve civarındaki askerî harekâtların büyük kısmı, Albay Deli Halit komutasında Kocaeli grup komutanlı̆g yürütülmüştür. Bu bölgenin işgalden kurtarılması aşamasına gelindiğinde Şükrü Naili Paşa (Gökberk) komutasındaki 3. Kolordu bu bölgeye sevk edilmiş, Bursa ve civarının kurtarılma harekâtı müşterek olarak gerçekleştirilmiştir. Çalışmada Bursa ve civarının kurtuluşu, 3. Kolordu Komutanı Şükrü Naili Paşa'nın Bursa Salnamesindeki hatıraları, Albay Deli Halit (Karsialan) komutasındaki Kocaeli Grubu'nun askerî faaliyetleri; Milli Mücadele'nin diğer cephe harekâtlarıyla bağlantılı olarak anlatılmıştır. Bursa'nın düşmana karşı konulmadan teslim edilmediği, kolaylıkla da kurtuluşa gidilmediği ve bu süreçte çok büyük mücadeleler verildiği görülmüştür.
\end{abstract}

Anahtar Kelimeler: Bursa, Şükrü Naili, Deli Halit, İşgal, Kurtuluş

\begin{abstract}
With the Mondeos armistice, initiated the occupation for Bursa. The occupation forces and the Istanbul government's attempts to people of Bursa were met by people and administrators, caused the Ankara government not take a definite position for a while. This uncertainty has led to the perception that Bursa and its surroundings are left to enemy and takeback with fight. Gemlik, Mudanya, Bursa and around during occupation and liberation were handled with military operations that led liberation of Anatolia.

the military operations around Bursa were carried out by Kocaeli group command of colonel Deli Halit. When the great offensive was achieved, the $3^{\text {rd }}$ corps was referred to this region. The commanding association was established the rescue operation of Bursa and its vicinity was carried out jointly.

In this study, liberation of Bursa and surroundings was explained by the memories of Şükrü Naili pasha and the military activities of the Kocaeli group command and other military operations of national struggle. It's seen that Bursa isn't delivered without being opposed and easily takeback.
\end{abstract}

Key Words: Bursa, Şükrü Naili, Deli Halit, Occupation, Liberation 


\section{Giriş}

I. Dünya savaşı sonunda Osmanlı Devleti ile galip devletlerarasında Mondros Mütarekesi imzalanmıştır. Mütareke hükümleri Osmanlı aleyhine olacak şekilde uygulanmaya başlamıştır. Bu doğrultuda galip devletler, mütarekenin 7. maddesini esas alarak stratejik öneme haiz toprakları işgal faaliyetlerine girişmişlerdir.

Ülke genelinde işgallerin başlamasına karşılık padişah ve Osmanlı Hükümeti; işgallere karşı ses çıkarmamayı, orduyu güçlendirmeye yönelmemeyi, işgal güçleri ile uzlaşı içinde varlıklarını devam ettirmeyi tercih etmişlerdir. Ankara merkezli direniş ve kurtuluş mücadelesine yönelik faaliyetleri söndürmek ve başarısızlığa uğratmak için de çeşitli kışkırtma ve olumsuz propaganda gibi faaliyetlerden geri kalmamışlardır.

Mondros ateşkes mütarekesi, tüm Osmanlı şehirleri gibi Bursa için de işgal sürecinin başlangıcı olmuştur. Bursa'yı işgale götüren fikkri süreçte şehrin zengin yeraltı-yerüstü varlıkları, ticari faaliyetlerinin yoğun olmasının yanında ilçeleri olan Mudanya ve Gemlik limanlarının kritik öneme sahip olmaları etkin rol oynamıştır. Ayrıca, İngilizlerin İstanbul'u ve boğazı işgal edip etrafında tampon bir bölge oluşturmak istemeleri de önemli bir faktör oluşturmuştur. Bu işgal sonucunda güvenliklerine tehdit oluşturan Ankara Hükümeti ile bu bölge arasındaki her türlü bağlantı; sevkiyat, haberleşme ve destek hareketlerinin önlenebileceği düşüncesi de Bursa ve civarının işgal edilmesi fikrini kuvvetlendirmiştir. Milli Mücadele'nin başlangıcında Ankara Hükümeti'nin Bursa ve bölgesini, dış cephe niteliği ile adlandırması fikri, İngilizlerin işgal öncesinde oluşturacakları tampon bölgenin merkezi olarak Bursa'yı düşünmesi odaklı oluşmuştur. Çünkü işgal süreci ve öncesinde bir süre Bursa ve bölgesinin; Ankara Hükümeti ile yol alıp almayacağı, durumun ne şekilde gelişeceği net olarak tahlil edilememiştir. İşgal güçlerinin, Bursa ve civarının işgali öncesinde, bu bölgede tampon bir devlet kurmak için faaliyetlerde bulunmalarına, bölge halkı ve şehir yöneticilerinin bir kısmının sıcak bakmaları da Ankara Hükümeti'nin Bursa ve bölgesinin işgalinde bir süre kesin tavır alamamasında etkili olmuştur.

Bursa ve bölgesinin işgal sürecinde karşı koyma halindeki belirsizlik, bu bölge ve Bursa'nın savaşılmadan düşman işgaline bırakılmış ve kurtarılmış gibi algılanmasına sebep teşkil etmiş̧tir. Bu durumun aydınlatılabilmesi için Bursa'nın kurtuluşu, Marmara bölgesi, sahil şeridindeki İznik, Orhangazi, Gemlik ve Mudanya'da gerçekleşmiş askerî harekâtlar, 3. Kolordu komutanı Şükrü Naili Paşa'nın Bursa salnamesinde yer alan hatıraları ve Albay Deli Halit'in komutasında olan Kocaeli Grubu'nun faaliyetleri üzerinden anlatılmaya çalışılmıştır. Ayrıca işgal ve kurtuluş sürecinde Bursa ve civarında meydana gelen tüm askerî harekâtlar; Anadolu'nun kurtuluşuna giden süreç ile bağlantılı olarak ele alınmıştır.

\section{Bursa'nın İşgaline Giden Süreçte Askerî Harekâtlar}

Mondros Mütarekesi'nin imzalanmasının ardından Yunan kuvvetleri 15 Mayıs 1919'da İzmir'e çıkışıtır. İzmir'e yapılan çıkarma ve işgalin ardından Yunan kuvvetleri, bir koldan deniz yolu ile Ayvalık istikametine, ikinci bir koldan İzmir'in kuzeyine, üçüncü bir koldan da İzmir'in doğusuna ilerlemeye başlamışlardır. Yunan kuvvetleri, batı Anadolu'nun içlerine doğru ilerlemelerini sürdürmüş, İtilaf Devletleri’nin adına Milne ${ }^{1}$ dedikleri hatta kadar ulaşmıştır. $\mathrm{Bu}$ hat üzerinde altı ay kadar bekleyen Yunan kuvvetleri; 22 Haziran

\footnotetext{
${ }^{1}$ Bu hat; Ayvalık-Kozluca kuzeyinden, Soma-Akhisar batısından, Manisa'nın kuzeyinden, Salihli'nin batısından, Aydın ve Ödemiş doğusundan geçerek Büyük Menderes boyunca uzanan hattı.
} 
1920'de genel bir taarruza geçmiştir. Yunanların taarruz planı; Türk kuvvetlerini doğuya atmak, İzmir bölgesinin emniyetini sağlamak daha sonra da Balıkesir üzerinden Marmara Denizi'ne ulaşmak şeklinde oluşturulmuştur. Taarruz öncesinde İngiliz donanması da Mudanya ve Gemlik sahillerine gelmiştir. 25 Haziran 1920'de Mudanya'ya çıkarma yapmışlar, önce Mudanya'da, ertesi gün Gemlik’te gösteri yürüyüşü düzenlemişlerdir. ${ }^{2}$ Böylece Bursa, işgal sürecine sokulmuştur. Yunan hükümeti, Bandırma-Balıkesir bölgesinde güvenliğin sağlanması, Bursa istikametinde gelişecek askerî harekâtın kolaylaştırılması için Mudanya ve Gemlik'in İngiliz birliklerince işgal edilmesini istemiştir. ${ }^{3} \mathrm{Bu}$ amacın gerçekleşmesi adına Mudanya ve Gemlik sahil kasabalarının işgali, İngiliz ve Yunan kuvvetlerinin ortak hareketleriyle gerçekleştirilmiştir. ${ }^{4}$

İngilizlerin Bursa'da yapılanma aşamasında olan milli mücadele taraftarlarına gözdağı vermek ve Yunanlara yardımcı olmak için gerçekleştirdiği Mudanya işgal harekâtı öncesinde, gelişmeleri yakından takip eden Ankara Hükümeti; Bursa'da bulunan 56. Tümen'e bağlı bir kısım birlikleri Bursa'dan Mudanya'ya göndermiştir. Mudanya'ya sevk edilen ve her bir bölük kuvveti 80-100 kişiden oluşan üç bölüklü bir tabur, Mudanya'nın güneyindeki Göktepe ve Hızır İlyas sırtlarına mevzilendirilmiştir. 2 Temmuz 1920 sabahı, 12 kadar gemiyle Mudanya'ya asker çıkarırken sahile hâkim mevzilerden açılan ateş üzerine bu teşebbüslerinden vazgeçen İngiliz filosu, bir muharebe gemisini bölgede bırakmış, kalan unsurları Gemlik Körfezi’nin kuzeyindeki armutlu açılarına demirlemişlerdir. 6 Temmuz 1920 sabahı, tekrar çıkarma harekâtına başlayan İngilizler, burada mevzilenmiş Türk kuvvetlerinin üzerine ateş açarak yaklaşık üç saat boyunca savunma hatlarını bombardımana tabii tutmuştur. Bunun üzerine 56. Tümen'in 173. Alayı'na mensup 6. ve 7. Bölüklerin siperleri yıkılmış, 7. Bölükten üç manga toprak altında kalmış 25 er şehit olmuştur. İngilizlerin bombardımanından daha fazla zarar görmemek için birlikler, Yörükali Köyü sırtlarına doğru geri çekilmiş̧ir. Bu durumdan faydalanan İngilizler karaya çıabilmişlerdir. Dar bir kıyı başından daha ileriye gidemeyen İngilizler, burada savunma hazırlıklarına başlamıştır. Ağır silahları ve topları olmayan Türk kuvvetleri, İngiliz donanmasından açılan ateşlerden sırtların gerisindeki siperlerde kalarak korunmuşlardır. İngiliz askerlerinin karaya çıkması üzerine, topluca baskı ateşi ile zayiat verdirmeye çalışmışlardır. Bu durum karşısında şaşkınlık içine düşen İngiliz filosu; ikinci defa yoğun topçu ateşlerini Türk savunma hatları üzerine tevcih etmiş ve bu şekilde askerlerini karaya çıkarmaya çalışmışırır. Bursa'dan beklenen destek gelemeyince Türk birlikleri sarsılmaya başlamış, bundan faydalanan İngiliz askerlerinin zeytinliklere kadar gelmesi, Türk mevziilerinin çözülmesine ve ardından dağılmasına sebep olmuştur. Buna karşın direnip ikinci bir savunma hattında tutunmaya çalışan Türk kuvvetleri, yoğun ateş altında kalmışlardır. Bu sırada geçit köyünden gönderilen bir tabur asker yeni siperlerde tutunmaya çalışmıştır. Ancak Demirtaş ve Filader Köyü’ndeki Rum çeteler, bu taburu arkadan kuşatarak ateş altına almışlardır. Havanın kararmasından yararlanan Türk kuvvetleri, geçit köyünden Hamitler Köyü'ne geri çekilebilmişlerdir. İngilizler, her ne kadar Bursa'daki Türk kuvvetlerinin sağ kanadına ve gerisine doğru bir

\footnotetext{
${ }^{2}$ Orhan Hülagü, Milli Mücadele'de Bursa, İstanbul 2001, s.94-100; 105-106.

${ }^{3}$ Yılmaz Akkılıç, Kurtuluş Savaşında Bursa, Bursa Kültür Sanat Turizm Vakfi, 1 Ocak 1997, s. 288.

${ }^{4}$ Sabahattin Özel, Kocaeli ve Sakarya İllerinde Milli Mücadele (1919-1922), Türkiyat Matbaacılık, İstanbul 1987, s. 115.
} 
harekâtta bulunmayıp, hedeflerini Mudanya'nın işgali ile mahdut tutmuş olsalar da Türk kuvvetlerinin bir kısmını Mudanya bölgesinde oyalayarak Yunanların Bursa’yı işgaline destek sağlamışlardır. ${ }^{5}$

Yunanlar, 30 Haziran 1920 günü, Balıkesir'i ele geçirdikten sonra bir kısım askerî birlik ile Kirmastı'ya kadar gelmiştir. 6. Piyade Alayı Muharebe Grubu'ndan oluşan Yunan birlikleri ${ }^{6}$, bu bölgede yeniden tertiplenme ve toparlanma sürecine geçmişlerdir. Bu esnada Limni adasından hareket eden Yunan askerî birlikleri ise 2 Temmuz 1920 günü, Erdek ve bandırma plajlarına çıkmıştır. Herhangi bir direnişle karşılaşmadan hızla ilerlemişler, Karacabey ve Susurluk istikametine yönelmişlerdir. Balıkesir-Kirmastı mıntıkasında bulunan Türk kuvvetlerini kuzeyden kuşatıp tamamen imha etmeyi hedef alan bu ileri harekât, Türk unsurlarının zamanında geri çekilmiş olması ile amacına ulaşamamıştır. Yunanların Kirmastı'ya 8-10 km mesafede bulunan Kavaklı Köyü'ne geldiklerini duyan halk, kasabanın yakılıp yıkılmasından korkmuş, bir heyet gönderip kasabaya zarar vermemeleri ricasında bulunmuştur. Kasabaya giren Yunanlar, işgalin ardından ileri harekâtla aynı gün (2 Temmuz 1920) Karacabey'i de işgal etmişlerdir.?

6 Temmuz 1920'de İngilizler, Mudanya ve Gemlik'i işgal ederken Yunanlar ileri harekâtlarının son hazırlıklarııı tamamlamaya koyulmuşlardır. 7 Temmuz 1920 sabahı, Yunan ileri harekâtı başlamıştır. 1. Süvari Tugayı'nın sağladığı örtme desteği (Kirmastıkaracabey hattında toplanma bölgesinde hazırlık halinde olan) ile 6. Piyade alayı muharebe grubu birlikleri, Apolyont Gölü’nün güneyinden ilerleyerek kayda değer bir direnişle karşılaşmaksızın Hasanağa-Akçalar bölgesine ulaşmıştır. Apolyont Gölü’nün kuzeyinden ilerleyen ve asıl taarruz gücünü oluşturan Adalar Tümeni'nin 4. Ve 5. Piyade alayları ile 28. Piyade alayı, Uluabat'taki köprünün Türk istihkâmcıları tarafindan kullanılamaz hale getirilmesi nedeniyle üç saatlik bir gecikme yaşamıştır. Bu birlikler, Apolyont Gölü bölgesinde balıkçlık yapan yerli Rumlardan sağlanan kayık, sandal gibi vasıta ve destekler ile gölün karşısına geçirilmiş, gecikmeli de olsa adalar tümeni birlikleri ilk hedefleri olan Badırga-Başköy bölgesine ulaşabilmişlerdir. ${ }^{8}$

8 Temmuz 1920 sabahı, saat 05.00 siralarında Yunan 1. Süvari tugayı, Bursa savunma cephesinin kuzey kanadını imha etmek maksadıyla kuşatma harekâtına girişmiş birlikler şose (asfalt olmayan yol) yollardan yürüyüşe geçmiştir. Sabaha karşı, Yunan Adalar Tümeni'nin üç ayrı istikametten üç ayrı hedefe taarruz etmesi planlanmıştır. Bu plan doğrultusunda, şoselerden kuşatma harekâtı için yürüyen Yunan 1. Süvari Tugayı'nın arkasından Yunan adalar tümeni harekete geçmiştir. Yunan 1. Süvari Tugayı'nın asıl taarruzunu üstlenen kuvvet, öğle saatlerine doğru minareli çavuş-balat köyü-koru istasyonu hattındaki Türk mevzilerinden açılan ateş karşısında bir süre duraklamak zorunda kalmıştır. Tekrar ilerleyebilmek maksadıyla bütün Yunan birliklerinin topçu ateşi bu bölgeye tevcih edilmiş yine de Türk mukavemeti kırılamamıştır. Böylece Yunan ilerleyişi bir müddet de olsa durdurulabilmiştir. Ancak, Yunan Adalar Tümeni'nin 4. Piyade Alayı'nın şiddetli ateş ve baskısı karşısında 56. Tümen'in 173. Alayı'na ait savunma mevziilerinde yer yer kırılma başlamıştır. Aynı zamanda 56. Tümen'in 174. Alayı, Yunan 6. Piyade Muharebe Grubu

\footnotetext{
${ }^{5}$ Hülagü, Milli Mücadele'de Bursa, s.106-109

${ }^{6}$ Akkılıç, Kurtuluş Savaşında Bursa, s. 293-294

${ }^{7}$ Hülagü, Milli Mücadele'de Bursa, s. 102-105

${ }^{8}$ Akkılıç, Kurtuluş Savaşında Bursa, s. 288-289; 293-294
} 
karşısında savunma mevziilerini terk edip geri çekilmek zorunda kalmıştır. Geri çekilen Türk birlikleri, Yunanlar tarafindan takip harekâtı ile rahat bırakılmamıştır. Türk birliklerinin geri çekilmesine yer yer Bursa halkı da katılmıştır. Bölgedeki yollar başlarında komutanları olanolamayan askerler, düzensiz birlikler ve halkla dolmuş, her yer insan seline dönmüş ve başarılı bir geri çekilme harekâtı icra edilememiştir. Bursa savunma cephesinin düzensiz bir şekilde dağılmasıyla 8 Temmuz 1920 günü, saat 15.00 civarlarında ilk Yunan birlikleri Bursa'ya girmişlerdir. Bursa'ya giren Yunan kuvvetleri, 9 Temmuz gününü dinlenme ile geçirmiş ardından çekilen Türk birliklerinin takibine devam etmiştir. Yunanlar karşısında mağlup olan ve düzenli bir çekilme harekâtı gerçekleştiremeyen Türk kuvvetleri, İnegölYenişehir hattından ilerlemek suretiyle Karaköy-Bozüyük bölgesine kadar çekilmişlerdir. ${ }^{9}$ Artık Yunanların hedeflerinin son noktası olan Bursa işgal edilmiş, amaçları gerçekleşmiştir. $\mathrm{Bu}$ işgalin sorumluları olarak 20. Kolordu Kumandanı Bekir Sami Bey, Bursa valisi hacim muhittin bey ve Alaşehir Kumandanı Aşir Bey gösterilmiştir. ${ }^{10}$ Oluşturulan işgal yönetimiyle halka eziyet etmeye başlanmış, soykırım ve tahribat hat safhalara ulaşmış, Bursa talan edilmiştir. ${ }^{11}$

\section{Bursa'nın Kurtuluşuna Giden Süreçte Askerî Harekâtlar}

\section{A. Kurtuluş Öncesi Askerî Harekâtlar}

Düzenli Türk ordusu henüz kuruluş ve organizasyon aşamasında iken Çerkez Ethem'in ayaklanması, Yunanlar tarafindan ileri harekâta firsat olarak görülmüştür. Anadolu içlerine ilerlemeyi düşünen General Papulas komutasındaki Yunan Küçük Asya Ordusu, 6 Ocak 1921'de, İnegöl ve Yenişehir üzerinden Eskişehir'e, uşak üzerinden de Afyonkarahisar'a doğru ileri harekâta geçmiştir. Birçok birlik Çerkez Ethem isyanıyla meşgul olduğundan harekete geçen Yunan ordusuna karşı koymak için, Eskişehir ilerleme bölgesini korumak üzere yalnızca 24. Tümen ile 11. Tümen'in bir alayı, Afyonkarahisar'da ise bir alaydan oluşan kuvvet bulundurulabilmiştir. Bu sebeple Yunan kuvvetleri karşısında bulunan Türk birlikleri, oyalama muharebeleri yaparak İnönü mevzilerine kadar çekilmiştir. $\mathrm{Bu}$ bölgede esas savunma hattı oluşturma kararı alınmıştır. Belirtilen kuvvetler arasında İnönü'de gerçekleşen muharebeler sonunda 14 Ocak 1921 günü Yunan birlikleri, 1. İnönü savaşı öncesinde bulundukları Kazancı-Koyunhisar-İznik Gölü güney çizgisine kadar geri çekilmişlerdir. Böylece Anadolu'nun içlerini ele geçirmeye yönelik ilk Yunan serüveni, kendileri açısından hayal kırıklığı ile sona ermiştir. ${ }^{12}$

I. İnönü Savaşı'nın kazanılmasının ardından batı cephesi komutanlığı, düşmanın Bursa ve civarındaki kuvvetlerini güçlendirdiğini görüp Yunanların İnönü’ye tekrar taarruz edebileceği çıkarımını yapmıştır. Ardından geniş batı cephesi ikiye bölünmüş, kuvvetlerin daha derli toplu hale getirilmesi sağlanmıştır. Bu maksatla Türk Batı Cephesi Komutanlığı'nın, 24 Ocak 1921 tarihli emriyle Kocaeli Grup Komutanlığı'nın kurulmasına

\footnotetext{
${ }^{9}$ Hülagü, Milli Mücadele'de Bursa, s. 132-138.

${ }^{10}$ Betül Batır, “Şükrü Naili Paşa ve Bursa'nın Kurtuluş Günü Hatıratı”, Atatürk Haftası Armağanı Dergisi, Genel Kurmay Personel Başkanlığı, Askerî Tarih ve Stratejik Etüt (ATASE) Daire Başkanlığı Yayını, S. 44, Kasım 2017, s. 68.

${ }^{11}$ Saime Yüceer, Bursa'nın İsgal ve Kurtuluş Süreci (8Temmuz 1920-11 Eylül 1922), Bursa 2001, s. 131-135; Adnan Sofuoğlu, "Osmanlı Arşiv Belgeleri Ișı̆̆ında Bursa", Atatürk Araştırma Merkezi, C.19, S.55, Mart 2003, s. 67-79;

${ }^{12}$ Akkılıç, Kurtuluş Savaşı'nda Bursa, s. 464-465
} 
karar verilmiştir. ${ }^{13}$ Doğrudan Genelkurmay Başkanlı̆̆ı'na bağlı olarak görev yapacak olan bu yeni birliğe komutan olarak Albay Halit görevlendirilmiştir. ${ }^{14}$ Bursa ve civarının kurtarılmasında yeni kurulan bu birlik başat rol oynamıştır.

İnönü muharebelerinde yenilen Yunanlar hem bu yenilgilerin olumsuz sonuçlarını gidermek hem de Ankara'yı etkisiz hâle getirip Sevr Antlaşması'nı kabul ettirmek için yeni bir harekâta gerek duymuştur. Bu doğrultuda başta Lloyd George olmak üzere İngiliz Hükümeti'nin desteği ile Anadolu'daki kuvvetlerini dinç birliklerle takviye ederek yeniden taarruza geçme kararı almıştır. Yunan Genelkurmayı'nın yeni stratejik planı; kuvvetlerinin büyük bölümünü Kütahya-Eskişehir bölgesinde bulunduran Türk ordusunu zayıf Bursa grubu ile oyalamak, kuvvetli uşak grubu ile Ankara'ya doğru çekilmesine firsat vermeden güneyden kuşatıp imha etmek şeklinde oluşturulmuştur. ${ }^{15}$

Sakarya'da Türk kuvvetleri ile Yunanlar arasında şiddetli çatışmalar devam ederken, General Papulas 4 Eylül'de, İzmit ve çevresini tekrar işgal etmek üzere başlatılacak harekâtı idare etmek amaciyla Bursa'ya gelmiş̧ir. Ancak 5 ve 6 Eylül günleri Sakarya'da General Papulas'ın ordusunun taarruzu durdurulmuş, Türk kuvvetleri 10 Eylül'de karşı taarruza geçmiştir. 13 Eylül'de Sakarya'nın doğusu Yunan kuvvetlerinden temizlenmiş, Eskişehir'e doğru çekilmekte olan Yunan kuvvetleri Sakarya'nın batısına geçen Türk kuvvetleri tarafindan takibe alınmıştır. Yunan kuvvetleri geri çekilirken İnönü Savaşları'nda olduğu gibi köyleri ve kasabaları yakıp yıkmaktan da geri kalmamıştır. ${ }^{16}$

Sakarya hezimetinden sonra Yunan kuvvetleri, Bursa'ya giden yolları kapatarak ulaşımı engellemek amacıyla kuvvetlerinin sol kanadını teşkil eden 3 alaylı 3. Kolordusu ile Eskişehir civarında, bu kolordunun 11. Alayı ile de Yenişehir civarında tertiplenmiştir. Türk taarruzu başladığında Yunanistan'ın 3. Kolordusunun yerinde sabit tutulup asıl meydan muhaberesinin cereyan edeceği afyon civarında bulunan Yunan asli kuvvetlerine katılmasını önlemek, Eskişehir civarında kalması halinde ise takip edilebilmesi için Türk 3. Kolordusunun 1. Piyade alayı ile mürettep süvari alayı, Döğer- Altıntaş - Kütahya üzerinden İnönü'ye hareket ettirilmiştir. ${ }^{17}$ (bkz. Ek 1).

16 Eylül 1921'de Albay Deli Halit'in komutasında kurulan Kocaeli Grubu'nu ${ }^{18}$ meydana getiren birlikler; 17. Tümen; her biri üçer taburlu olmak üzere 61., 62. ve 63. Piyade Alaylarından oluşturulmuştur. Ayrıca doğrudan tümene bağlı birliklerden tümen hücum taburu, tümen topçu taburu, tümen süvari takımı, tümen sthhiye bölüğü ve tümen cephane kolu teşkil edilmiştir. Tümen birliklerine ait ağır makineli tüfek sayısı 13, hafif makineli tüfek sayısı 13, kudretli dağ topu sayısı 6 adet olarak belirlenmiştir. Kocaeli bölgesindeki gönüllülerden oluşan süvari tugayı; 21. Süvari alayı, mürettep tabur (Geyve ve İzmit bölüklerinden oluşan), Öcalan ve Akhisar (Pamukova) müfrezelerinden meydana gelen Mürettep Müfreze'den teşkil edilmiştir. Bu birliğin akıncı kolu, istihkâm müfrezesi, sapanca müfrezesi ve beş seri ateşli, iki toplu dağ bataryasından oluşturulmuştur. Süvari alayı; iki ağır, iki hafif süvari, 260'1 piyade olmak üzere 300 mevcutlu Albay Deli Halit pehlivan

\footnotetext{
${ }^{13}$ Özel, Kocaeli ve Sakarya İllerinde Milli Mücadele (1919-1922), s. 122.

${ }^{14}$ Kazım Aras, İstiklâl Savaşında Kocaeli Bölgesindeki Harekât, 102 Sayılı Askeri Mecmua, İstanbul, 1936, s. 101.

${ }^{15}$ İbrahim Artuç, Büyük Dönemeç Sakarya Meydan Muharebesi, Kastaş Yayınevi, İstanbul, 1985, s. 30-32

${ }^{16}$ Nutuk, C.2, s. 617.

${ }^{17}$ Bursa Salnamesi, 1927, s. 57.

${ }^{18}$ Özel, Kocaeli ve Sakarya İllerinde Milli Mücadele (1919-1922), s. 168.
} 
müfrezesi, bağımsız süvari müfrezesi ve Ereğli Bahriye Müfrezesinden oluşmuştur. Grup karargâhında süvari bölüğü ve piyade bölügü ile 4 . Seyyar hastane mevcut tutulmuştur. Grup karargâhındaki birliklere iki ağır, beş hafif makineli tüfek tahsis edilebilmiştir. ${ }^{19}$

Yapılan yeni düzenleme ve teşkilatlanmalar neticesinde Marmara Bölgesi’ndeki Türk millî kuvvetlerini oluşturan Kocaeli Grubu birlikleri, Bursa'y1 savunmak üzere; İznik gölü kuzeyi-Yeniköy doğusu-keramet köyünün batı hattında, 18. Tümen'in hücum taburu, Esadiye-Elmalı-Gacık çevresinin batı hattında Yalova Bölüğü ve jandarma birlikleri, Mekece bölgesinde 18. Tümen karargâhıyla iki alayı, İznik kuzey doğusu- KaradinOsmaneli hattında, Bilecik'in kuzeyinde 5 subay, 48 silahlı erden kurulu ve otomatik tüfeklerle desteklenmiş iki akıncı birliği ile Bilecik kuzeyinden başlayarak Söğüt'ün batısına kadar uzanan hatta ise yerli halk müfrezeleri hazır bulundurulmuştur. Türk ordusunun bu tertiplenmesine karşıllk bölgedeki Yunan birlikleri, Bilecik'in güneyindeki Küplü’nün doğusu ile İznik Gölü arası hattında, 11. Tümen karargâhı ve birlikleri; komuta yerleri Gemlik'te bulunan iki piyade taburu, İznik gölü batı kıyısı Gemlik Körfezi arası hattında; bu iki piyade taburunun 6 top ile destekli tüm bölükleri, Bursa merkezde; 47. Piyade Alayı'nın iki taburu, yeni Sölöz bölgesinde, 47. Piyade Alayı'nın 3. Taburu olacak şekilde tertiplendirilmiştir. ${ }^{20}$

Aralık 1921'de bir tabur dolayındaki Yunan birliği Gemlik bölgesinden Orhangazi yönünde ilerleyerek bazı köylere girmiş ancak Yalova- Orhangazi yolunun doğusuna geçmeye teşebbüs etmemiştir. Küçük Asya Ordusu Kuzey Grubu'nun emrinde bir askerî bölge komutanlığı kurulmuştur. Ayrıca, Mart 1922'den itibaren Yunan askerî güçlerinin yapı, destek ve konumlarında bazı değişikliklere gidilmiştir. Birinci hattaki birlikler, muhtemel bir Türk saldırısına karşı bazı destek birlikleriyle güçlendirilmeye çalışılmıştır. Stratejik öneme haiz Bursa-İnegöl-Karaköy yolunun güvenliğinin sağlanması amacıyla yol boyunca istihkâm birlikleri görevlendirilmiştir. ${ }^{21}$

Cephe hatlarında gelişen yeni durumlara reaksiyon gösterebilmek için sürekli birlik görev yeri değişimleri, görevlendirmeler, kaydırmalar ve yeniden tertiplenmeler gelişiyordu. Marmara ve Bursa çevresi hattından sorumlu Kocaeli grup komutanlığı Ağustos 1922'de; 18. Piyade tümeni (iki alaylı), mürettep süvari tümeni (iki alayl1), bağımsız İzmit Taburu, 19. Hücum taburu, 20. Hücum taburu, bağımsız Yalova Bölügü̈, 1. Ve 2. Akıncı bölükleri, süvari bölüğü, süvari takımı, muhabere bölüğ̈̈, karargâh muhafız takımı, 14. Seyyar hastane, 6,5 tonluk deve kolu $^{22}$ birliklerden oluşturulmuştur. Yukarıda ifade edilen Türk kuvvetlerinin karşısında bulunan Bursa bölgesindeki Yunan mevzileri ise Gemlik körfezi-kumla İskelesi’nden İznik Gölü’ne dayandırılmıştır. Mevzilerin sınırı, İznik gölü doğusundan olmak üzere Bilecik-Söğüt ve Bozdağ'in da doğusundan geçen alaçam ve Alkin hattına kadar uzatılmıştır. 6 Ağustos'tan itibaren Gemlik, Orhangazi, İznik, Bilecik hattındaki Türk ve Yunan birlikleri sıcak temasa geçmişlerdir. 29-30 Ağustos gecesi Kocaeli gurup Komutanlığı'na bağlı birlikler ise Bursa üzerine taarruz etmek üzere yürüyüşe geçirilmiştir.

\footnotetext{
${ }^{19}$ Aras, "İstiklâl Savaşında Kocaeli Bölgesindeki Harekât", s. 118-119.

${ }^{20}$ Akkılıç, Kurtuluş Savaşında Bursa, s.568.

${ }^{21}$ Victor Dusmanis, Küçük Asya Harbi nin İçyüzü, (Çev. Hristo Ertorun), Genelkurmay Harp Tarihi Başkanlığı Kütüphanesi, 1928, s. 98.

${ }^{22}$ Genelkurmay ATASE Yayını, IV. Cilt, 1. Kitap, Genelkurmay Matbaası, Ankara 1984, s. 311.
} 
Bu sırada Eskişehir bölgesindeki Yunan birliklerinde geri çekilme işaretlerinin görülmesi üzerine 31 Ağustos günü batı cephesi komutanlığı, Kocaeli Grup Komutanlığı'na Orhangazi'yi hızla aşıp Bursa'ya varması, Bursa ile İzmir arasındaki harekât yollarını kesip Yunan kuvvetlerinin yürüyüşünün durdurulması emrini vermiş̧tir. Yunan birlikleri ise mevcut kuvvetlerine ilave olarak Trakya'da bulunan Yunan 55. Alayı'nı da gemilerle getirerek Gemlik'e çıkartmıştır. ${ }^{23}$

Türk ordusu 26 Ağustos 1922'de, Yunanlara karşı büyük bir taarruza geçmiş, harekât Türk kuvvetlerinin zaferi doğrultusunda gelişmiştir. Yunan ordusu dağınık bir şekilde geri çekilmeye başlamıştır. ${ }^{24} \mathrm{Bu}$ arada Bursa'da, özellikle Eskişehir-Bilecik yönlerinden gelen göçmenler ve çeteler sebebiyle şehirde telaş ve kargaşa hâkim olmaya başlamıştır. ${ }^{25}$

26 Ağustos 1922 sabahı alaca karanlıkta başlayan Türk taarruzu, afyon bölgesinde planlandığı gibi hızla gelişmiş, Yunanların ve batılı gözlemcilerin aşılamaz diye böbürlendikleri Yunan savunma mevzileri (Milne Hattı) daha ilk hamlede yarılmış ve Yunan birlikleri düzensiz bir şekilde geri çekilmeye başlamıştır. Afyon-uşak-İzmir hattında bunlar yaşanırken kuzeyde Eskişehir-Bursa hattında bulunan güneydekiler kadar yıpranmamış, 3 . Yunan kolordusu, ağırlıklarını Eskişehir bölgesine kaydırmış ve Bursa istikametinde çekilme hazırlıklarına başlamıştır. Talihin ve tarihin garip bir cilvesi olarak bu Yunan 3. Kolordusunun karşısında Türk 3. Kolordusu taarruz için görevlendirilmiştir. ${ }^{26}$

Batı cephesi komutanlığı, 31 Ağustos 1922 saat 09.00'da Kocaeli Grup Komutanlığı'na:

"perişan ve mağlup durumdaki Yunan ordusunun büyük klsmı, Eskişehir cephesinden çekilenlerle birlikte Bursa ve oradan hizla İzmir yönüne giderek Milne Hattı'nı tutmaya çalışacakları değerlendirilebilir. Grubunuzca tasarladı̆̆ınız harekât yalnız Orhangazi'ye hâkim olmakla kalmayıp, bu bölgeyi süratle aşarak Bursa'ya varmak olmall. Yunan kuvvetleri Bursa dolaylarında üstün durumda iseler, Kocaeli müfrezenizle Bursa ile İzmir arasındaki harekât yolları üzerinde düşman yürüyüşünü devamlı olarak kesmeye yönelmeli. Müfreze sikıntılar yaşadı̆̆ında bile ufak gruplar haline geçerek yine yolları kesmeli. Ordularımızın 15 gün içinde İzmir önüne gelmesi hesaplanmuştır. İaşe mahallinden temin olunabilir, yalnız cephane beraberinizde olacaktır. Mümkünse harekâtın çabuklaştırılması... "27 emrini vermiştir.

Alınan tedbirler neticesinde, Eskişehir civarındaki Yunan 3. Kolordusunun, 29-30 Ağustos'ta afyon kuzeybatısında cereyan eden büyük meydan muharebesine katılamaması Sağlanmıştır. Ancak bu kolordunun geri çekilişine engel olunamamış, Yunan 3. Kolordusu Eskişehir'den çekilmeyi başarmış ve Şükrü Naili Paşa ${ }^{28}$ komutasındaki Türk 3. Kolordusu,

\footnotetext{
${ }^{23}$ Mümtaz Şükrü Eğilmez, Milli Mücadelede Bursa, (hzl. İhsan Ilgar), İstanbul 1981, s. 148-151

${ }^{24}$ Nutuk, C.2, s. 674

${ }^{25}$ Eğilmez, Milli Mücadele'de Bursa, s. 147

${ }^{26}$ Fahri Belen, Büyük Türk Zaferi Afyon'dan İzmir'e, İstiklâl Harbi Hatıraları, Tenkitler, Tahliller, Doğuş Ltd. Şirketi Matbaas1, Ankara 1962, s.76

${ }^{27}$ Türk Ístiklâl Harbi, II cilt, Batı Cephesi, 6. Kısım, III. Kitap, s. 32.

${ }^{28}$ Milli Mücadele Dönemi’nin önemli şahsiyetlerinden biri olan 3. Kolordu Komutanı Şükrü Naili Paşa, Bursa şehrinin işgalden kurtulduğu günleri, cephe planlarını Bursa Salnamesinde hatırat olarak kaleme almıştır.
} 
İnönü civarında sadece düşmanın dağınık artçı unsurlarına yetişebilmiştir. Bu artçılar, Türk 3. Kolordusunun baskı ve taarruzlarına dayanamayarak (Karaköy- Pazarcık- İnegöl- Bursa) istikametinden hızla geri çekilmişlerdir. ${ }^{29}$

Kocaeli grup karargâhı ise İznik'in kuzeyinde Hisardere'ye ulaşabilmiştir. 19. Hücum taburu Dumanlı Tepe'nin güney-batısını tıkamış, İznik gölü kuzeyinde Üreğil-Karlık Dağı batısı-dumanlı tepe arası yine gözetleme postalarıla kontrol edilmeye başlanmıştır. Dumanlı tepe-Soğucak arasındaki hâkim tepelerde ise tesis edilen direnek noktalarıyla, muhtemel bir Yunan taarruzuna karşı tedbirler alınmıştır. Binbaşı Mustafa Bey kumandasında teşkil edilen beş tabur ve iki dağ bataryasından oluşan mürettep müfreze Yalova kesiminde görevlendirilmiştir. ${ }^{30}$

31 Ağustos'ta, Albay Deli Halit ve karargâhı Hisardere'den Yörükler'e kadar gelerek ileri harekâta geçebilmiştir. Müfreze unsurları, İznik gölü kuzeyinden batıya doğru yürümüş, 31 Ağustos 1922 sabaha karşı Orhaniye bölgesine ulaşmıştır. ${ }^{31}$

Türk batı cephesi Komutanlığı'nın Albay Deli Halit'e verdiği emirden ve Şükrü Naili Paşa'nın hatıratından anlaşılan odur ki güneyde afyon cephesinden yıpranmadan ayrılmayı başarabilen Yunanların 3. Kolordusuna bağlı 3. ve 10. Tümenler, Eskişehir'i hızla boşaltıp Bursa'ya doğru düzenli bir şekilde çekilmeye başlamışlardır. ${ }^{32} \mathrm{Bu}$ tümenler, Bursa'nın doğu ve kuzeydoğusunda mevzide bulunan Yunan 11. Tümen ve Gemlik bölgesinde bulunan bağımsız 47. Alay ile birleşerek Balıkesir'e doğru çekilip, Milne Hattı'nı yeniden ve güçlü bir şekilde savunmaya geçmeyi hedeflemişlerdir. Böyle bir durumda Yunan kuvvetleri, Türk ordusunun İzmir'e ulaşmasını geciktirebilir hatta tümüyle engelleyebilirdi. $\mathrm{Bu}$ sebeple başlangıçta Yunan 11. Tümeni ve bağımsız 47. Alayı'nı bulundukları yerde tutma görevi verilmiş olan Kocaeli Grubu'na, “taarruzlarını, üstün düşmanla karşılaşsa bile Bursa'ya kadar geliştirmesi ve Yunan ordusunun Bursa'dan İzmir'e çekilme yollarının kesilmesi” emri verilmiştir. ${ }^{33}$

Albay Deli Halit, batı cephesi Komutanlığı'ndan aldığı bu yeni emri yerine getirmek üzere, birliklerini yeniden teşkilatlandırmaya başlamıştır. 1 Eylül gününe kadar başlangıçta verilen emir gereğince Kocaeli Grubu bölgesinde kesin sonuç alıcı bir taarruza girişilmemiş, düşman oyalanıp yerinde tespit (yerinde kalması) edilmiştir. ${ }^{34}$

31 Ağustos'ta Albay Deli Halit komutasındaki Kocaeli grup karargâhı, Kızderbent'e ulaşmıştır. Bağımsız Yalova bölüğü ile 19. Hücum taburu cephelerinde bir değişiklik olmamıştır. Mürettep müfreze, 31 Ağustos /1 Eylül 1922 gecesi intikaline devam etmiş, 1 Eylül sabahı erken saatlerde İznik gölü kuzeyinden boyalıca üzerinden bayındır yoluyla Kızderbent'e gelmiştir. 18. Tümen ve Rus bataryaları, İznik Gölü ile Bilecik arasında Yunan 11. Tümeni ile muharebe halini sürdürmüştür. ${ }^{35}$

2 Eylül 1922'de çekilmekte olan Yunan 3. Kolordusunu takip eden 3. Türk kolordusuna bağlı porsuk müfrezesi, Eskişehir’i işgalden kurtarmış ilerlemesine devam eden

\footnotetext{
${ }^{29}$ Bursa Salnamesi, 1927, s. 57

${ }^{30}$ Belen, Büyük Türk Zaferi Afyon'dan İmir'e, s.76

${ }^{31}$ Türk İstiklâl Harbi, II cilt, Batı Cephesi, 6. Kısım, III. Kitap, s. 31

${ }^{32}$ Bursa Salnamesi, 1927, s. 57

${ }^{33}$ Türk Istiklâl Harbi, II cilt, Batı Cephesi, 6. Kısım, III. Kitap, s. 32

${ }^{34}$ Türk İstiklâl Harbi, II cilt, Batı Cephesi, 6. Kısım, III. Kitap, s. 212

${ }^{35}$ Türk İstiklâl Harbi, II cilt, Batı Cephesi, 6. Kısım, III. Kitap, s. 212
} 
kolordu ise İnönü’ye ulaşmıştır. ${ }^{36}$ Güneyde ise 2 Eylül 1922 günü Yunan Küçükasya Ordusu Başkomutanı General Trikupis'le birçok Yunan generali ve yüksek rütbeli subaylar da uşak civarında esir alınmıştır. ${ }^{37}$

Aynı vakitlerde Albay Deli Halit ve Kocaeli grup komutanlığı karargâhı ise Gacık Köyüne gelmiştir. Mürettep müfreze unsurları sabah erken saatlerde, Kirazlı-Elmalı-Gacık bölgesine intikallerini tamamlamıştır. Albay Deli Halit, Duman Tepe'de 19. Hücum Taburu'nun cephesindeki son durumu yerinde gördükten sonra, Soğucak üzerinden Beşpınar Tepe'ye geçmiş, keşif ve gözetlemelerden Yunanların Gemlik körfezi ile İznik gölü arasındaki hattı kuvvetle tahkim etmiş olduklarını görmüş̧ür. Türk batı cephesi komutanlığı, kuvvetle tahkim edilmiş bu hattın bir noktadan yarılıp, Bursa bölgesinde bulunan 3. Yunan Kolordusunun geri bölgesine sızılıp kolordunun düzenli geri çekilişinin engellenmesini emretmiştir. Bu emir doğrultusunda yapılmış plana göre: Kocaeli grup komutanlığ birlikleri, düşman savunma direncini kırmak ve mevzilerini terk ederek çekilmesini sağlamak maksadıyla, 4 Eylül sabahı güneş doğarken batıdan-doğuya bağımsız İzmit taburu, bağımsız Yalova bölüğü, 18. Hücum taburu, 19. Hücum taburu 1. Hatta 3. Piyade taburu ihtiyatta olmak üzere siklet merkezi Kurtköy güneyindeki 838 rakımlı Elmalı Dağ-966 rakımlı Fındıklı tepe-Gemlik istikametinde olmak üzere yapacağı taarruzla Gemlik bölgesini ele geçirme görevini üstlenmişlerdir. ${ }^{38}$

Yapılan bu plan çerçevesinde, kirazlı köyü civarında bulunan bağımsız İzmit taburu 3 Eylül 1922 günü saat 19.00 'da bulunduğu bölgeden hareketle, Soğucak-Kurtköy-Beşpınar tepesi yoluyla 869 rakımlı Samanlı Dağı'na hareket etmişti. Samanlı Dăğ'na gelinmesinin ardından buranın güney hattında savunma düzeni alınmış; 4 Eylül 1922 sabahı bağımsız Yalova bölüğü elmalı dağını ele geçirdikten sonra 867 rakımlı tepeye taarruza geçmişti. Esadiye-Kurtköy arasında bulunan bağımsız Yalova bölügü, grup karargâhı muhafiz takımını emrine alarak, 3 Eylül 1922 günü öğleden sonra Beşpınar Tepe'ye ulaşıp ertesi gün yapılacak taarruz için hazırlıkları başlatmıştır. Bağımsız Yalova bölüğü, grup karargâhı muhafız takımını emrine almış, 4 Eylül 1922 sabahı asıl taarruz gücü olan 18. Hücum taburu ile harekâtını koordine etmiştir. 838 rakımlı Elmalı Dağ'a kuzey batıdan taarruz edip, kendisine tahsis edilen hedefi ele geçirip müteakip harekâta hazır olma görevi ile harekete geçmiştir. ${ }^{39}$

3 Eylül 1922 günü mürettep müfreze unsurları, saat 19.00'da harekete geçmiş, 18. Hücum taburu ise öncü olarak Kurtköy'e girmiştir. Mürettep Müfreze Komutanı'nın emrindeki bu birlikler -3. Taburu eksik olarak- 4 Eylül 1922 sabahı, 838 rakımlı Elmalı Dağ'a kuzey ve kuzey doğudan taarruza geçmiştir. Cephesi çok geniş olan 19. Hücum taburu, 4 Eylül 1922 sabahı, Üreğil-Duman Tepe arasında uygun gördüğü bölgelerde dikkati kendi üzerine çekmek için gösteri taarruzları yapmıştır. 19. Hücum tabur komutanı, bir takımını bir Şinayder top bataryası ile denizden olası bir düşman çıkarmasına karşı koymak için Yalova'ya göndermiştir. Bir topu eksik Şinayder top bataryas1, Esadiye bölgesinde mevzilenmiş ve 4 Eylül 1922 sabahı taarruz başladığında Reşadiye istinat noktasını ateş altına almıştır. Burası piyade unsurları tarafından ele geçirilince ileri doğru mevzi

\footnotetext{
${ }^{36}$ Bursa Salnamesi, 1927, s. 57; Yılmaz Akkılıç, Kurtuluş Savaşı'nda Bursa, İkinci Kitap/İşgalden Kurtuluşa, s. 581.

37 İbrahim Özkan, Deli Halit Paşa Unutulan Yullar, Unutturulan Kahraman, s. 295

38 Özkan, Deli Halit Paşa Unutulan Yillar, Unutturulan Kahraman, s. 295-296

${ }^{39}$ Ahmet Akyol, Bir Kahramanlk Destanı Bağımsı Yalova Bölï̈̆̈̈, 1. Baskı, Diner Ofset, Yalova, Haziran 2005, s. 36
} 
değiştirilmiş, 15. Piyade Alayı'nın taarruzu ateşlerle desteklenmişti. Grup süvari bölüğü de Yalova Bursa şosesini kesmek üzere Soğucak Köyü civarında tertiplenmişti. 15. Alay’ın 3. Taburu, Yalova Bölge Komutanı Yarbay İsmail Hakkı Bey'in emrinde, Reşadiye Köyü'nün $2 \mathrm{~km}$. Kuzeyindeki istinat noktasına (568 rakımlı tepe) taarruz için Kurtköy doğusunda taarruz mevziilerine girmiştir. Bu tabur, Reşadiye istinat noktasını ele geçirdikten sonra topçuyu korumak üzere bir bölüğünü bırakıp Beşpınar’a geçmiş ve müfreze ihtiyatı görevini üstlenmiștir. ${ }^{40}$

Esadiye-Kurtköy arasında Bursa Yalova şosesini kapatan bağımsız Yalova Bölüğü, yerini süvari bölüğüne bırakmış, akşam karanlığında Beşpınar Tepe'ye gelmişti. Grup karargâhı muhafız takımını emrine alan bölük komutanı, bölük unsurlarını sabah erken saatte yapacağı taarruz için tertiplemiştir. Albay Deli Halit komutasında sol kol olan 15. Alay ve üç toplu kudretli dağ bataryası, 18. Hücum Taburu'nun öncülüğünde 3 Eylül saat 19.00'da Kirazlı-Elmalı'dan hareketle Kurtköy'e ulaşmıştır. Bu arada Şinayder top bataryası, Esadiye bölgesine mevzilendirilmiştir. Yapılan bütün bu hazırlıkların tamamlanmasından sonra oyalama ve gösteri taarruzları sona ermiş, artık Yunanların tıpkı afyon-uşak cephelerinde olduğu gibi imha edilmeleri vakti gelmiştir. Biran evvel Gemlik ve Mudanya'nın ele geçirilip bu iki önemli limanın kapatılması şart olmuştur. Bu maksatla 4 Eylül 1922 sabahı yapılacak taarruz harekâtı için her türlü hazırlık tamamlanmıştır. ${ }^{41}$

4 Eylül 1922 tarihinde, Kocaeli Grubu birlikleri taarruz için hazır hale gelmiştir. Karşılarında bulunan Yunan kuvvetleri, İznik gölü ile Gemlik körfezi arasındaki bütün tepeleri direnek noktası olarak hazırlamış ve kendilerince kritik gördükleri tepeleri de dikenli tellerle çevirmişlerdir. Bağımsız 47. Yunan alayı, Esadiye Direnek noktasının doğusundaki Yalova-Bursa şosesinden Dumanlı Tepe'ye giden tepeler hattından Yeniköy'e uzanıp İznik Gölü’nde sona eren bir savunma hattı hazırlamıştır. Türk taarruzlarına karşı tüm tedbirlerini almış beklemeye geçmişlerdir. $\mathrm{Bu}$ savunma hattı bölgesinde, 1. Yunan taburu görevlendirilmiştir. 3. Yunan taburu ise reşadiye direnek noktası-Elmalı Dağ-Fındıklı Tepe (Karaincir Tepe)-Şahin Tepe-Papazuçtu Tepe-Gemlik kuzeyi hattında kuzeye karşı savunma için tertiplenmiştir. 2. Yunan taburu ise Orhangazi batısında ihtiyatta bulundurulmuştur. Cephedeki Yunan taburlarını desteklemek üzere dört toplu $120 \mathrm{~mm}$ 'lik bir batarya, bir sahra ve bir büyük dağ bataryası ayrılmıştır. Trakya'dan getirilip Gemlik'e çıarılan 55. Yunan piyade alayı da gelişecek durumlara göre süratle kullanılmak için hazır hale getirilmiştir. ${ }^{42}$

Yunanların bu tertiplenmesine karşlık Kocaeli Grubu birliklerinden Kurtköy'de toplanmış olan mürettep müfreze, saat 03.00 'te 18 . Hücum taburu öncüde olmak üzere tek kolda yürüyüşe geçmiştir. Bağımsız Yalova bölüğü ile grup muhafız takımı, karanlıkta büyük bir sessizlik içinde elmalı dağ batı mevziilerine yanaşmış ve hava ağarırken baskınla hücuma kalkmıştır. Elmalı Dağ'da bulunan ve Orhangazi'ye doğru taarruza geçen Türk 15. Alayı'nın 1. Ve 2. Taburlarının harekâtı, Yunanlar tarafindan durdurulmuştur. ${ }^{43}$

4 Eylül 1922 gecesinde yapılan muharebelerde, Yunan savunma mevzilerinin birinci hatları ele geçirilmiştir. 5 Eylül günü planlanan taarruz için 18. Tümen'in emrinde kalan 24.

\footnotetext{
${ }^{40}$ Akyol, Bağımsız Yalova Bölüğ̈̈, s. 36

${ }^{41}$ Türk İstiklâl Harbi, II cilt, Batı Cephesi, 6. Kısım, III. Kitap, s. 222

${ }^{42}$ Türk İstiklâl Harbi, II cilt, Batı Cephesi, 6. Kısım, III. Kitap, s. 223

${ }^{43}$ ATASE Arşivi, No:5/6534, Kls. 2224, Dos. 51, Fih:1-17.
} 
Alay'ın 2. Taburu da Albay Deli Halit'in emriyle, İznik Gölü’nün kuzey kıyısından yürüyüp Üreğil'e ulaşmış ve mürettep müfreze emrine girmiştir. ${ }^{44}$

4 / 5 Eylül 1922 de Yunanlar, 1. Taburlarını geri çekmişlerdir. Çekilen birlikler, Orhangazi-Kaleönü ve batısı hattını takviye etmekle yetinmişlerdir. Gemlik'e takviye için trakya'dan getirilen Yunan 55. Alayı da Büyükbeyli-Papazuçtu-Kü̧̈ükkumla hattını tutmuştur. Bütün Yunan cephesinin emir komutasını 55. Yunan alay komutanı üstlenmiştir. Böylelikle Yunanlar şahin tepe güneyindeki Papazuçtu Tepesi-Kaleönü-Orhangazi hattını kuvvetli bir şekilde tutarak bütün cephenin emir komutasını da tek elde toplamışlardır. Kocaeli grubu, 5 Eylül 1922’ de, Yunanlılara karşı taarruzlarını devam ettirmiş̧i. Sabah saat 05.00'ten itibaren Orhangazi yönünde yapılan Türk taarruzları, Findıklı Köyü'nün güneydoğu sırtlarında durmuştur. Daha batıdaki Şahin Tepe'de bulunan bağımsız İzmit Taburu ile 18. Hücum taburu bölgesinde ise Yunan askerlerinin inatçı savunmasıyla karşılaşılmış hem de Gemlik Körfezi’nde bulunan Yunan gemilerinden açılan şiddetli top ateşlerine maruz kalınmıştır. Bağımsız İzmit Taburu başlangıçta biraz ilerleyebilmişse de Yunanların denizden ve karadan açtı̆̆ topçu ateşleriyle desteklenen karşı taarruzları karşısında geri çekilmek zorunda kalmıştır. Türk birlikleri tarafindan bir gün önce ele geçirilmiş ve kritik öneme haiz yerlerden biri olan şahin tepe kaybedilmiştir. ${ }^{45}$

5 Eylül günü yapılan bütün Türk taarruzlarının, 11. Yunan Tümeni’nin 47. ve 55 . Alaylarının inatçı direnişi karşısında sonuçsuz kaldığını gören Albay Deli Halit, Orhangazi batı sırtlarından taarruz ederek ovaya inmeye karar vermiştir. ${ }^{46}$ Ancak ileri hatlara gönderdiği Harekât Şube Müdürü'nden aldığı yeni bir rapor üzerine bu planından vazgeçmiş ve gece saat 24.00'ten itibaren Orhangazi-Gemlik-Bursa istikametinde yeni bir taarruz plan1 hazırlamaya karar vermiştir. Bu plan gereğince de 6 Eylül sabahına kadar topçularla takviyeli üç taburluk bir kuvveti, Hamzalı Köy bölgesinde taarruz için tertiplemeye başlamıştır. ${ }^{47}$

6 Eylül 1922'ye gelindiğinde Yunanların Anadolu'daki asıl güçlerini oluşturan güney kolordularının, Başkomutanlık Meydan Savaşı'nda büyük kayıplar verip İzmir'e doğru çekilmeye başlaması, kuzeydeki 3. Kolordularını Marmara'nın güneyinde sıkışıp kalma tehlikesiyle karşı karşıya bırakmışıı. Bu bakımdan Yunan kolordu komutanı, Bursa kuzeyindeki Orhangazi kesiminin savunulmasının hayati önemde olduğunu anlamıştı. Bölgeye 55. Yunan alayı da gönderilmiş, birlikler takviye edilmiş ve savunma mevzileri derinliğine kuvvetlendirilmiștir. ${ }^{48}$

3. Yunan kolordu komutan1, geri çekilen birliklerini kurtarabilmek, gemilerle Yunanistan'a kaçırabilmek maksadıyla Gemlik, Mudanya ve bandırma iskelelerinden faydalanmayı düşünmüştür. Çünkü bu bölgenin savunulması Yunanlar açısından hayatî öneme haizdir. 55. Alay ile takviye edilmiş olmalarına rağmen Gemlik bölgesinden alınan raporlardan Yunan birliklerinin durumunun iyi olmadığı anlaşılmıştır. Albay Deli Halit'in komuta ettiği Kocaeli Grubu, savunmadaki Yunan birliklerini zor duruma düşürmüştür. İlave önlemler alınması ve savunmanın güçlendirilmesi gerekmiştir. Bu amaçla Yunan komutanı,

\footnotetext{
${ }^{44}$ Rasim Koçal, Kocaeli Burhaniye Kuvayı Milliye Müfreze Kumandanı Rasim Koçal'nn Milli Mücadele Hattratt, s. 32.

${ }^{45}$ Akyol, Bir Kahramanlık Destanı Bağımsı Yalova Bölüğ̈̈, s. 44

${ }^{46}$ ATASE Arșivi, No: 5/6534, Kls. 2224, Dos. 52, Fih:1-97.

${ }^{47}$ Özkan, Deli Halit Paşa Unutulan Yillar, Unutturulan Kahraman, s. 300-301

${ }^{48}$ Akkılıç, Kurtuluş Savaşında Bursa, s.584.
} 
5/6 Eylül gecesi Bursa bölgesindeki Yunan Alayı'ndan iki tabur, bağımsız muhafız taburu ve takviyeli bir sahra topçu taburundan oluşan kuvveti, Albay Jiras komutasında 100 kamyonla Gemlik'e göndermiştir. ${ }^{49}$ Türk tarafinda ise Albay Deli Halit, 5 Eylül günü oldukça yıpranmış ve durmak zorunda kalmış birliklerini, yeni bir taarruz için Hamzalı Köy bölgesinde yeniden tertiplemeye ve teşkilâtlandırmaya başlamıştır.

Türk 3. Kolordu unsurları, 6 Eylül'de Yenişehir-İnegöl hattına ulaşmıştır. Türk 3. Kolordusu İnegöl'e doğru ilerlemiş ${ }^{50}$, Kocaeli Grubu birlikleri de Bilecik ve Yenişehir'i ele geçirmiştir. Yunan kuvvetleri de- 3., 10. ve 11. Tümenleri ile- Bursa doğusunda evvelce tahkim edilen kazancı bayırı mevziinde tutunmayı başarmışlardır. ${ }^{51}$

İki tarafi tepelere dayalı, çok iyi tahkim edilmiş ve iki kat fazla kuvvetle oluşturulmuş donanmasının topçu ateşi ile desteklenen Yunan savunma hattına karşı, 6 taburdan ibaret olan Kocaeli müfrezesi ile yapılacak bir taarruzdan ilk aşamada çok fazla başarı beklenmemiştir. Yunanlar bu bölgede, üç tümen ve dört piyade alayı toplamışlardır. Yunanlar, Türk kuvvetlerine karşı üçte bir nispetinde üstünlüğü sağlamışlardır. Üstelik bu kuvvetler şimdiye kadar olan muharebelerde yıpranmamışlardır. ${ }^{52}$

7 Eylül 1922'de, Kocaeli Grubu unsurlarının taarruzları saat 14.00’te başlamıştır. Başlayan şiddetli taarruzla birinci Yunan savunma hatları ele geçirilmiştir. Uzun süreden beri Yunanlarca özel olarak derinliğine engellerle tahkim edildiğinden taarruz çok zor ilerleyebilmiştir. Taarruza katılan Türk birliklerinin başlangıç mevcudu 6 tabur olup takviye edilmediğinden kayıplarla erimiştir. Buna karşıllk savunmadaki Yunan kuvvetleri, üç piyade alayı (10 tabur kadar kuvvet) ve 35 toptan oluşturulmuştur. Aynı zamanda taarruz bölgesinin büyük bir kısmı Gemlik Körfezi'nde konuşlanmış olan Yunan savaş gemilerinin atış menzili içinde olduğundan Türk birlikleri bir de bunların topçu ateşlerine maruz kalmıştır. ${ }^{53}$

8 Eylül 1922 tarihinde, Kocaeli Grubu birlikleri bölgesinde önemli bir olay olmamıştır. Türk birlikleri çekildikleri Hamzalı Köyde hem yeni bir taarruz için hazırlıklarını tamamlamış hem de istirahat etmişlerdir. Kurtuluş öncesinde Bursa merkezi, bağlı yerleşim yerleri ve çevre bölgelerde yaşanan tam manası ile kurtarma, işgali sonlandırma boyutlu olamayan bu askerî gelişmeler, kurtuluşa gidecek zaman ve harekâta zemin hazırlamıştır. ${ }^{54}$

\section{B. Kurtuluşa Yönelik Askerî Harekâtlar}

Bursa'nın işgalinden 5 Eylül 1922 tarihine kadar geçen süre zarfında Bursa ve bölgesindeki kapsamlı askerî faaliyetler, Kocaeli grup komutanlığ 1 birlikleri ile yerel milis güçleri tarafindan ifa edilmiştir. Bölgede bulunan Yunan 3. Kolordusu Eskişehir hattına yanaşmıştır. Türk 3. Kolordusu tarafindan başarı ile uygulanan bölme harekâtı sonucunda, bu Yunan kolordusu muharebelere katılıp destek sağlayamamıştır. Ancak, yıpranmadan geri çekilmek suretiyle tekrar Bursa bölgesine gelmiş ve zinde bir şekilde yeni harekâtlar için hazır beklemiştir. Türk batı cephesi komutanlığı, büyük taarruzun başarı ile ilerlemesinin sonucunda yıpranmış olan Kocaeli Grubu'nu da emri altına alarak Bursa ve civarını kurtarma

\footnotetext{
${ }^{49}$ Belen, Büyük Türk Zaferi Afyon'dan Izmir'e, s. 100

${ }^{50}$ Bursa Salnamesi, s. 57

${ }^{51}$ Türk İstiklâl Harbi, II cilt, Batı Cephesi, 6. Kısım, III. Kitap, s. 229.

${ }^{52}$ Belen, Büyük Türk Zaferi Afyon'dan İzmir'e, İstiklâl Harbi Hatıraları, Tenkitler, Tahliller, s.102

${ }^{53}$ Belen, Büyük Türk Zaferi Afyon'dan İzmir'e, İstiklâl Harbi Hatıraları, Tenkitler, Tahliller, s.103

${ }^{54}$ ATASE Arşivi, No:4/4478, Kls.1765, Dos. 123, Fih: 64.
} 
harekâtını yürütmek üzere 3. Kolordunun görevlendirilmesine karar vermiştir. Bu maksatla batı cephesi komutanlı̆̆ı, 5 Eylül 1922 günü, saat 23.00’te verdiği bir emirle, Albay Deli Halit komutasındaki Kocaeli Grubu'nun harekât bakımından Şükrü Naili Paşa komutasındaki 3. Kolordu’ya bağlandığını bildirmiştir. Bu emir, ancak 7 Eylül 1922 günü saat 09.00 'da 3. Kolordu' ya ulaşabilmiștir. ${ }^{55}$

Türk ordusu İzmir'e kadar ilerlemiş Mustafa Kemal Paşa, Genelkurmay Başkanı ve Batı Cephesi Komutanı ile durumu incelemiş ve Şükrü Naili Paşa komutasındaki 3. Kolordu'ya "Bursa'nın 10 Eylül'de düşmandan kurtarlması" emrini vermiştir. 8 Eylül 1922 'den itibaren fiili olarak 3. Kolordu emrinde olan Kocaeli Grubu komutanı Albay Deli Halit' e de Gemlik-Mudanya sahil şeridinin kesilmesi bildirilmiştir. ${ }^{56} \mathrm{Bu}$ durumda Bursa ve civarında bulunan Yunan kuvvetlerine yapılacak taarruzların, Eskişehir-Bozüyük-Bilecik istikametinden Bursa'ya doğru ilerleyen Şükrü Naili Paşa kumandasındaki 3. Kolordu ${ }^{57}$ ile Kocaeli grup komutanlığı arasında tesis edilecek koordine ile icra edilmesi şart olmuştur. ${ }^{58}$

8 Eylül 1922 tarihine kadar komşu birlik olmanın ötesinde 3. Kolordunun Kocaeli Grubu ile herhangi bir bağlantısı olmamıştır. Sadece 18. Tümen'in öncü unsurları, Yenişehir kesimine yaklaştı̆̆ında bu iki birlik arasında irtibat kurulmuştur. Bu tümen aracıllğııla 8 Eylül'de Kocaeli Grubu'na; 3. Kolordu emrine bağlanmış olduğu, ara hatlarının YenişehirBursa şosesi olduğu bildirilebilmiş ve emir komuta birliği tesis edilmiştir. ${ }^{59} 8 / 9$ Eylül gecesi İnegöl'e varmış olan Şükrü Naili Paşa ${ }^{60}$ Kocaeli Grubu'nun gönderdiği raporları okumuş, durumu değerlendirdikten sonra grubun durmaksızın taarruzlarına devam etmesi emrini vermiştir. Verdiği emirle Kocaeli Grubu; Yunan kuvvetlerinin yeni savunma hatları kurmalarına, yeni tahkimatlarla mevziilerini güçlendirmelerine firsat vermemek için; geceleri baskın tarzında şiddetli taarruzlar yapmalı, böylece düşmanın toparlanmasına izin verilmemeli fikrini harekete geçirmeyi hedeflemiştir. ${ }^{61}$

Türk 3. Kolordusu İnegöl'e ulaştı̆ında, Yunan kuvvetlerinin uzun zamanda inşa ettikleri ve Gemlik'in kuzeyinde bulunan Samanlıdağ-Dimboz-Kazancı hattındaki mevzilerine girdikleri ve kendilerini almaya gelecek gemilerin Mudanya'ya ulaşmasına kadar beklemeye karar verdikleri anlaşılmıştır. Şükrü naili paşa, düşmanın bu hatta tutunmasına firsat vermenin, düşmanın bütün malzemeleri ile tüm askerlerini, kolayca kaçırmasına müsaade etmek demek olacağını, düşünmü̈ştür. Bu düşünceden hareketle 8 Eylül 1922 günü, akşamüzeri icra edilmek üzere bir taarruz planlamış, hazırlıklar başlatılmıştır. Bu taarruzun asıl unsurunu teşkil edecek olan 1. Alay, Halhalca'nın $2 \mathrm{~km}$ batısında, Yenişehir-İnegöl istikametinde Bursa'yı birleştiren yolların üzerindeki hâkim noktalara yerleştirilmiştir. Akşamüzeri başlayan muharebede tel örgülerle tahkim edilmiş savunma mevziilerinin birinci hatları aşılmış ve mevziilerin tamamı düşürülmüştür. Akabinde Samanlıdağ-Dimboz istikametinde taarruz harekâtına devam edilmiş, bölgedeki Yunan askerleri temizlenmiş, hedeflenen tepeler ele geçirilmiştir. Türk 3. Kolordusunun bu taarruzu neticesinde, Yunanların kuvvetle tahkim edilmiş olan hatlarda kaçış gemilerini

\footnotetext{
${ }^{55}$ ATASE Arşivi, No:4/4478, Kls.1765, Dos. 123, Fih: 64

${ }^{56}$ Cemal Kutay, Ege'nin Kurtuluşu, Boğaziçi Yayınları, İstanbul 1981, s. 167

${ }^{57}$ Bursa Salnamesi, s. 57

${ }^{58}$ ATASE Arşivi, No:4/4478, Kls.1765, Dos. 123, Fih: 64

${ }^{59}$ Türk İstiklâl Harbi, II cilt, Batı Cephesi, 6. Kısım, III. Kitap, s.232.

${ }^{60}$ Bursa Salnamesi, s. 58

${ }^{61}$ ATASE Arşivi, No:6/6083, Kls. 2334, Dos. 5, Fih:88
} 
beklemek için zaman geçirme düşünceleri boşa çıkartılmıştır (bk. Ek 2). 9 Eylül 1922 günü, Yunanlar, muhtelif bölge ve mahallelerde küçük-zayıf birliklerle Türk ordusunun kazandığ başarılı harekâtlara karşı taarruz ve baskın tarzı harekâtlara girişmiştir. Ancak, askerlerinin moral bozukluğu ve isteksiz olmalarının da etkisiyle başarı sağlamamıştır. Giriştikleri tüm faaliyetler, moral üstünlüğüne de sahip Türk birlikleri tarafindan süratle püskürtülmüştür. 9 Eylül'de keşiş dağı eteklerinde bulunan Yunan kuvvetlerinin, yan gerilerine çıartılan keşif kolları vasıtası ile akşamüzerinden itibaren geri çekilme hazırlıkları içerisinde oldukları öğrenilmiştir. Şükrü naili paşa; Yunan birliklerinin her ne kadar çekilme harekâtına başlamış olsalar da iki yanlarını Marmara denizi ve keşiş dağı gibi aşılması güç iki engele dayadıkları için yanlarından dolaşarak önlerini kesmek suretiyle geri çekilmelerinin önlenmesinin mümkün olmadığı fikrini taşımaktadır. Bu fikir dolayısıyla Yunan birliklerinin tek değil tüm yönlerden takip edilebilmesi için harekâta hazırlanılmış, istikametlerin bildirilmesi ile harekâta başlanılmıştır. ${ }^{62}$

10 Eylül 1922'de, İzmir'in kurtarıldığı haberini alan batı cephesi komutanlığı; 3. Kolordu'ya gönderdiği bir telgraf ile bu olayı müjdelemiş hem de 3. Kolordu'nun, Kocaeli Grubu ile birlikte Bursa cephesindeki düşmanı takip edip genel bir taarruza geçmesi emrini vermiştir. ${ }^{63}$

Şükrü naili paşa komutasındaki 3. Türk kolordusu; 10 Eylül 1922 şafak vaktinden itibaren Yunan birliklerini sıkı takip harekâtına başlamıştı. 3. Kolordu süvari alayı, saat 09.00 civarında Bursa'nın doğu sınırının son noktasına ulaşmıştı. Süvari Alayı'nın Yunan unsurlarını hızla takip edebilmesi için hiçbir engele takılmaması gerekiyordu. Bu sebeple Türk süvari alayı, Yunan artçı birliklerinin engelleme harekâtlarına takılmadan düşmanın gerilerine geçip takip etmeyi sürdürebilecek mahiyetli bir tarz içerisinde olmalıydı. Bursa'da bulunan Yunan kuvvetlerinin faaliyetlerine rağmen Türk süvari alayı, hızla düşmanın geri bölgesine geçip Bursa-Mudanya yolunu kesmiş ve Samanl1-Umurbey üzerinden nilüfer vadisi istikametinde hareketine devam etmiştir. Bu harekât esnasında 3. Türk kolordu karargâh1, Kestel'in güneyinde bulunan yüksek bir tepeden Bursa'da cereyan eden muharebelerin seyrini izlemiş, gelen raporları da değerlendirip gelişmeleri harita üzerine şu ifadeler doğrultusunda işaretlemiştir:

"Türk birliklerinin sağ kanadında bulunan Kocaeli Grubu; iki kol halinde bir kol Gemlik-Umurbey- Tepederbend istikametinde, diğer kol Adliye-Muradoba istikametinde düşmana taarruz ediyordu. 18. Fırka, Dışkaya dağını ele geçirip tutunabilmek maksadı ile Yunanlılara hücum için hazırlanıyordu. Yunan birlikleri ise Gemlik'in güney sırtlarındaki Dışkaya dağında halen direnmeye, tutunmaya çalışı topçu unsurları ile 18. Türk firkasını, ateş altında bulunduruyordu. Tüm bunlar olurken bir alay kadar Yunan birliği, ağırlıklarıyla birlikte iğdir-kazıklı arasından batı istikametine doğru hızlı yürüyüşle kaçmaya çabalıyordu. Dimboz-Kestel-Bursa hattı üzerinde bulunan yol boyunca ilerleyen 61. Türk alayı; iğdirkazıklı arasındaki Yunan piyade alayının yolunu kesip imha etmek için hızla Susığırlık üzerinden Kazıklı'ya sevk edilmiş, burada bu iki birlik arasında yeni bir muharebe başlamıştı.” (bk. Ek 3). 10 Eylül günü, Aksu-Kestel yolu üzerinden Bursa istikametinde ilerleyen 1. Fırka ile 3. Kolordu Süvari Tümeni'ne bağlı bir birlik; Bursa-Gemlik arasındaki yolu kesmiş, Umurbey-Panayır Köyü civarında düşmanın otomobil kollarını yakalamış ve

\footnotetext{
${ }^{62}$ Bursa Salnamesi, s. 58-59.

${ }^{63}$ Kutay, Ege'nin Kurtuluşu, s. 167.
} 
Bursa'dan Gemlik'e giden 11. Yunan Tümeni'nin kurmay başkanını ele geçirmiştir. Sorgulama sonunda Bursa'da iki Yunan tümeninin bulunduğu, bu tümenlerin gelişen durum karşısında Mudanya'ya çekilecekleri ve gemilerle oradan ayrilacakları bilgisine ulaşılmıştır. 3. Türk kolordusu için çok önemli iki hedef ortaya çıkmıştır. Birisi Bursa'nın düşman tarafindan yakılıp yıkılmadan ve en az zayiatla kurtarılması, diğeri ise Gemlik-Deliçay arasındaki bataklık bölgede derhal imha edilmesi gereken bir düşman kuvvetinin bulunması idi. Bu doğrultuda hedeflerin ele geçirilmesi maksadıyla kuvvetlerin uygun şekilde sevk ve idaresi gerekmekteydi. Sağ kanatta yani bataklık ile Gemlik arasında muharebeyi şiddetlendirerek Yunan askerlerini püskürtmek, onların hem kaçmalarına zemin hazırlayabilir hem de imha olmaktan kurtulmalarını sağlayabilirdi. Bu sebeple düşmanın geri bölgesine geçip tüm kaçış yollarını kapatmak gerekiyordu. Bu maksatla Türk süvari firkası, bataklık bölgedeki Yunan unsurları ile Bursa'da bulunan Yunan artçı kuvvetleri arasındaki alana girip iki Yunan birliğinin irtibatlarını kesmiştir. ${ }^{64}$

Bu gelişmeler yaşanırken 1. Türk piyade firkası Bursa'ya yaklaşmıştır. Yunanların kaçarak imha olmaktan kurtulmalarına mâni olmak için süvari firkası, Bursa'da bulunan düşman kuvvetlerini dikkate almadan Mudanya istikametine sevk edilmiştir. Bursa'ya yaklaşan 1. Fırkaya da Bursa istikametinde ilerleyip düşman artçılarının bertaraf edilmesi vazifesi verilmiştir. Yunanların işgalleri süresince stratejik noktalara yerleştirdiği topçu bataryalarının şiddetli ateşi, Türk piyadelerinin hızlı ilerleyişlerinin kesilmesine sebebiyet vermiştir. Akşam vakitlerine doğru 1. Türk firkasının bir kısım unsurları, düşman topçu ateşlerine rağmen Bursa'nın güney bölgesi ile tren istasyonunu ele geçirebilmiştir. Bu hamle ile Bursa 10 Eylül 1922 akşamı, düşmandan kısmen kurtarılmış oluyordu. Türk süvari firkası, 10 Eylül gecesinde Bursa- Mudanya yolunu düşman işgalinden kurtarmış, bu yol üzerinden kaçıp kurtulmayı hedefleyen 15 Yunan subayı ile 400 kadar düşman askerini imha etmiştir. ${ }^{65}$

Albay Deli Halit, 10 Eylül 1922 günü birliklerini "sağ ve sol kol" olarak ikiye ayırmıştı. Sağ kolun emir komutasını 15. Piyade Alay Komutanı'na, sol kolun emir komutasını ise Binbaşı Mustafa'ya vermiştir. Sağ kolu 15. Piyade Alayı'nın 1. Ve 3. Piyade taburları, 18. Hücum Taburu, bağımsız İzmit Taburu, Bağımsız Yalova Bölüğü ve Şinayder top bataryasi; sol kolu ise 24. Piyade alay12. Piyade taburu, 15. Piyade alay1 2. Piyade taburu, 19. Hücum taburu ve kudretli dağ bataryası oluşturmuştur. Kocaeli grubu birliklerini bu şekilde yeniden teşkilâtlandıran, kendisi de sol taarruz kolunda bulunan Albay Deli Halit, 10 Eylül sabahı saat 08.30 'da verdiği taarruz emrinde: "sağ kolun Şahin Tepe'yi ele geçirip, Orhangazi-Gemlik şosesini kesmesini, sol kolun ise Orhangazi'yi ele geçirmesini" bildirmiştir. Albay Deli Halit'in bu emrini alan birlikler saat 09.00'dan itibaren harekete geçmiş, böylece iki kolun müssterek harekâtı ile taarruz saat 10.30'da başlamıştır. Yunanlar son güçleriyle direnmeye çalışıorlardı. Çünkü bu tepeleri ve Orhangazi'yi kaybederlerse Gemlik'i de kaybedeceklerini iyi biliyorlardı. Sol taarruz kolu, önce Hamzalı-Fındıklı Hattına yanaşmıştır. Ardından şiddetle hücuma kalkan sol kol unsurları, Yunanları sarsılamaz birer direnek noktası olarak hazırladıkları mevziilerinden püskürtmeyi başarmıştır. Orhangazi kasabasının doğu tarafından taarruz eden sol taarruz kolu, başlarında bulunan Albay Deli Halit ile birlikte düşmanı bulundukları mevziilerinden sökerek geri

\footnotetext{
${ }^{64}$ Bursa Salnamesi, s. 59

${ }^{65}$ Bursa Salnamesi, s. 60
} 
atmayı başarmış ve saat 11.00'de Orhangazi’ye girmiştir. Böylece Yunan işgali boyunca tecavüzlerin, katliamların, büyük acıların yaşandığı, birkaç kez yakılıp yıkılmış olan Orhangazi kasabası da kurtarılmıştır. ${ }^{66}$

10 Eylül 1922'de Orhangazi kurtarılmış, bölgedeki en kritik arazilerden birisi konumunda olan şahin tepe ele geçirilmiştir. Artık bir an önce Gemlik'in de kurtarılıp buradan gemilerle kaçmaya çalışan Yunan artıklarının, hareket ve faaliyetlerinin engellenmesi gerekiyordu. Bu sırada Orhangazi' den çekilen Yunanların bir kısmı da Göldere Vadisi'nin güney sırtlarında Karsak-Umurbey hattında savunma hattı oluşturmaya çalışıyordu. $\mathrm{Bu}$ bölgedeki Yunanlara da yeniden savunabilmeleri için tertiplenebilecek zaman bırakmamak lâzımdı. Bunun için ileri harekâta devam eden Albay Deli Halit, saat 14.00’te Gedelek Köyü batısındaki sırtlara ulaşmıştı. Albay Deli Halit; sol taarruz kolunun katırlı istikametinde taarruzlarına devam etmesini, koordineli olarak sağ taarruz kolunun da Gemlik’i düşman işgalinden kurtarıp, Küçükbeyli (Cihatlı) Umurbey üzerinden Engürücük güneyindeki Bursa yolu-şosesine hâkim 250 rakımlı tepeye ilerlemesini bildirmiştir. Gemlik’te adeta bir ana baba günü yaşanmıştır. Türk birliklerinin karşısından kaçmayı başarabilen Yunan birliklerinin bir kısmı; Gemlik'te bekleyen gemilere sığamadıkları için binememiş, kıyı boyunca geriye doğru ilerlemiş, Kurşunlu-Altıntaş üzerinden Mudanya’ya ulaşmaya çabalamıştır. Gayrimüslim nüfusun yoğun olduğu Gemlik'te hayat âdeta felce uğramış ve şehirde kargaşa oluşmuştur. Hristiyan halkın önemli bir bölümü kaçıp gitmiş, kaçamayanların bir kısmı korku ve tedirginlik içinde evlerine çekilmiş bir kısmı da bir yolunu bulup gemilere binebilmek umuduyla limanı, iskeleleri, sahil kıyılarını doldurmuş endişe içinde beklemeye başlamışlardır. ${ }^{67}$

Gemlik'te bunlar yaşanırken Albay Deli Halit'in verdiği emir üzerine sağ taarruz kolu üç taburla Göldere Vadisi'nin güneyine geçmiştir. Karsak-Umurbey hattındaki Yunanlılarla muharebeye tutuşup, kısa süre içinde püskürtüp Umurbey'in güney tepelerini ele geçirmiştir. Sol taarruz kolu ise ilerlemesine devam etmiş, Yunanların etkisini yitirmiş topçu ateşi altında ovayı hızla geçip adliye dolaylarına ulaşmıştır. Gemlik' in kurtarılması yolunda en kritik yer olan Papazuçtu Tepesi (Soğucak Tepe), Yunanlar tarafindan halen elde tutulmakta buradaki Yunan savunması Gemlik Körfezi'nde bulunan savaş gemilerinin ateşleriyle de desteklenmekteydi. Papazuçtu Tepesi'ne taarruz eden bağımsız İzmit Taburu ve bağımsız Yalova bölüğü düşmanla çok şiddetli bir muharebeye girişmiştir. Yunan savaş gemilerinin topçu ateşleriyle desteklenen ve sürekli takviye alan Yunan kuvvetleri inatla direndikleri için Türk taarruzlarında bir gelişme sağlanamamıştır. Türk unsurları, taarruzlarını gece de sürdürmüş, yaptıkları süngü hücumlarıyla Papazuçtu Tepesi'ni ele geçirmiş, gece yarısı saat 24.00'te Gemlik'e girmeyi başarmıştır. Bu muharebeler esnasında Türk mürettep müfrezesi, beş subay ve seksen eri şehit vermişti. Yunan Jiras Müfrezesi birliklerinde ise Papazuçtu Tepe'de; 3 subay, 14 er ölmüş, 3 subay ile 63 er yaralanmıştır. Bu müfrezenin çok az bir kısmı Gemlik'ten vapurlara binebilmiştir. Kalan Yunan askerleri, birçok alet-edevat ve teçhizatını Gemlik’te bırakıp kıyı yolu ile Gündoğdu tepelerine doğru çekilmiş, sabah 06.00'dan itibaren savunma mevzilerine girmişlerdir. ${ }^{68}$

\footnotetext{
${ }^{66}$ ATASE Arşivi, No:5/6534, Kls. 2224, Dos. 51, Fih:1-17.

${ }^{67}$ Akkılıç, Kurtuluş Savaşında Bursa, s. 590

${ }^{68}$ Türk İstiklâl Harbi, II cilt, Batı Cephesi, 6. Kısım, III. Kitap, s. 238-239; 242.
} 
Şükrü Naili Paşa'nın 3. Kolordu birlikleri ise 10 Eylül sabahı erkenden Bursa istikametine yürüyüşe geçmiştir. Süvari tümeni, Bursa'ya yaklaştı̆̆ında düşmanın topçu ve makineli tüfek ateşleriyle karşılaşmıştır. Yunanlılar, Bursa'nın doğusunda ışıklar sırtlarını diğer ifade ile şehrin doğu yakasını tutmuş, Yıldırım Camii'ne de makineli tüfekler yerleştirmiş̧ir. Süvari tümeni meskûn mahalde yapılacak muharebeyi arkadan gelen 1 . Tümen'e bırakmış, büyük kısmı ile Bursa-Gemlik şosesini kesmek üzere şehrin kuzeyine hareket etmiştir. $\mathrm{Bu}$ arada meskûn mahalde yapılacak cephe taarruzunun zorluğunu düşünmüş olan 1. Tümen de Bursa'ya yaklaşmış olmasına rağmen 1şılar askerî lisesinin ve kutsal mabetlerin tahripten korunmasını temin etmek için şehre giriş yapmak üzere bir alay bırakıp büyük kısmı ile şehrin kuzeyine yönelmiştir. Yaptığ 1 taarruzlarla ileri harekâtını sürdüren 3. Türk Kolordusu'nun piyade ve süvari birlikleri, 10 Eylül akşamı, Yunanları püskürtmüş ve Bursa'ya girmeyi başarmıştır. ${ }^{69}$ Albay Deli Halit Komutasındaki Kocaeli Grubu ve Şükrü Naili Paşa komutasındaki 3. Kolordu, 10 Eylül gecesinden itibaren tüm Bursa'yı Yunan işgalinden kurtarmıştır. ${ }^{70}$

11 Eylül 1922 sabahından itibaren Bursa, işgalden kurtarılmış ancak henüz asıl hedef olan tüm bölgenin işgalden kurtarılması, düşmanın yakalanarak imha edilmesi gerçekleştirilememiştir. Henüz Yunan unsurlarının Mudanya istikametinde bulabilecekleri kaçış yolları tamamen kapatılamamıştır. Bu amaçla, Türk süvari firkası sabah erkenden Tepederbend bölgesinde konuşlanmış, Gemlik sahil istikametinden Mudanya'ya ulaşmak isteyen Yunan unsurlarının bir kısmını şiddetli topçu ateşiyle Mudanya'ya ilerleyemeden imha etmiştir. 11 Eylül akşamüzeri Yunan askerleri Filader'in güney ve doğu sırtlarında, Maskara Hasan- Aksungur- Göynüklü mıntıkasında şaşkın bir vaziyette üç tarafindan -doğu, güney, batı- Türk birlikleri ile sıkıştırılmış ve muharebeye zorlanmıştır. ${ }^{71}$

Bursa merkezi ve Gemlik'in kurtarılmasından sonra sırada Mudanya ve bandırma kalmıştır. Yunan askeri dağınık halde sadece buralarda tutunabilmiștir. 3. Türk Kolordusu'nun süvari tümeni; Bursa'dan Mudanya istikametinde ilerlerken Albay Deli Halit komutasında Kocaeli Grubu ise Gemlik'i kurtarmış, ileri harekâtına devam etmiş, Mudanya'yı savunan Yunan kuvvetlerine karşı taarruza geçmiştir.

11 Eylül 1922 günü, saat 03.00’te, Kocaeli Grubu'nun sol taarruz kolu birlikleri, saat 07.00'de ise sağ taarruz kolu birlikleri Muratoba bölgesine ulaşmıştır. Deli Halit paşa ise gece yarısı Muratoba'ya gelip, durumu yakından incelemek üzere Engürücük'e doğru hareket etmiş ve sabah 05.30'da Yumurtatepe'ye gelip 08.30'da bütün birliklerine;

Yunan birlikleri 10/11 Eylül gecesi Gemlik'i boşaltarak kaçmak zorunda birakildl. Mürettep müfreze ivedilikle Umurbey-EngürücükGöynüklü hattından Mudanya'ya geçecek, süvari bölüğ̈̈ aynı yoldan ilerleyip 3. Kolordu unsurlarl ile irtibat kuracak, grup muhafiz takımı Gemlik'te kalacak, topçu komutanı Gemlik mevkii komutanllğı görevini yürütüp ele geçen araç, gereç ve donanımı muhafaza görevine devam edecek. ${ }^{72}$ emrini vermiştir.

\footnotetext{
${ }^{69}$ Belen, Büyük Türk Zaferi Afyon'dan İmir'e, s 103.

${ }^{70}$ Özkan, Deli Halit Paşa, s. 310-311

${ }^{71}$ Bursa Salnamesi, 1927, s. 61.

${ }^{72}$ ATASE Arşivi, No:5/6534, Kls.2224, Dos. 51, Fih:119.
} 
Saat 17.00 'de taarruz başlamıştı. Hava kararmasına rağmen taarruza devam edilmiş ve saat 20.00 civarında, Gündoğdu Tepe'nin doğusunda bulunan sirtlar süngü hücumuyla ele geçirilmişti. Yunanlar, Gündoğdu Köyü batısında bulunan Çiftkaya Tepe ile bu tepenin güneyinde bulunan Çapa Tepe'de yeni mevzilerde savunma yapabilmek için tertiplenmeye başlamıştır. Kocaeli grup komutanlığı birlikleri kaçan Yunan askerlerini takibe etmiş, Gündoğdu Köyü civarında dört dağ obüsü ile çok sayıda cephane ele geçirmişti. Ateşe verdikleri Çiftkayalar-Çapa hattında tekrar direnmek isteyen Yunanlara, tekrar taarruz edilmiş ve saat 24.00 'te süngü hücumu ile bu tepeler tamamen ele geçirilmiştir. GemlikBursa şosesi, Yunanlar tarafindan birakılan çok miktarda erzak, cephane ve arabalarla dolmuş̧ur. ${ }^{73}$ Yunan Jiras müfrezesi şiddetli Türk taarruzları karşısında 11/12 Eylül 1922 gecesi, Göynüklü-Burgaz yolu ile Mudanya'ya çekilmeye başlamıştır. ${ }^{74}$

Mudanya; rıhtımda bekleyen Fransız gemileri, karaya çıkmış iki bölük kadar Fransız askeri ile birlikte sığınmak veya gemilerle Yunanistan'a kaçmak için gelen on binlerce Rum, cepheden kaçan Yunan askeri ve silahlı çeteler ile dolmuştur. Mudanya'da adeta mahşer günü yaşanmaya başlamıştı. Mudanya'daki bu karmaşa 27 Ağustos'tan itibaren devam etmiştir. ${ }^{75}$

Kocaeli grup komutanı Albay Deli Halit, Göynüklü Köyü’nün güney tepesine çıkmış ve Mudanya bölgesine yönelik bir gözetleme yapmıştır. Yaptı̆̆ gözetlemede; Mudanya limanında önemli sayıda savaş ve nakliye gemilerinin bulunduğunu, Göynüklü'den Burgaz'a çekilen karma bir kol olduğunu, Tepederbent'ten kuzguncuk yönüne giden bir piyade taburunu, Tepederbent civarında mevziiye giren topçu unsurlarını, 16., 47. ve 55. Yunan Alayları'ndan oluşan Jiras Müfrezesi'nin Mudanya'ya çekildiklerini ve 11. Yunan Tümeni'nin 17. Alayı'nın da Burgaz'a ilerlediğini tespit etmişti. Bu gözetleme sonuçlarının değerlendirilmesinin ardından Albay Deli Halit emrindeki birlikler, Göynüklü’nün doğu ve güneyindeki sırtlara taarruz ettirilmiş̧tir. Mudanya'nın kuzeyinde ise deniz kıyısından ilerleyen 15. Piyade Alayı'nın 1. Taburu, karşısında bulunan Yunan 17. Piyade Alayı'nı süngü hücumu ile püskürtmüş, saat 11.00'de Burgaz'a girmiştir. Kocaeli grubu taarruzlarına devam edip Yunanlara ağır zayiatlar verdirmiş, burgaz'ı ve batısındaki dalyan'ı ele geçirmiş̧ir. Albay Deli Halit 18. Tümen Müfrezesi'ni Mudanya'ya sevk etmiş, grup komutanlığı birliklerini de Burgaz batısında toplayıp Mudanya üzerine intikali başlatmıştır. Daha batıdan Bursa-Mudanya yolu mihverinden ilerleyen 1. Tümen unsurları da saat 13.00 'te Mudanya'ya girmiştir. ${ }^{76}$

Yunan 11. Tümeni'nin tamamı Mudanya'da esir alınmış, Jiras müfrezesi ise Çiftekaya Tepesi'nde bozulduktan sonra Mudanya'ya çekilebilmişti. Burada da durumun kötüleştiğini gören Jiras müfrezesi, hiç durmadan Trilye Yolu'ndan kaçışla Karacabey’e geçmiştir. ${ }^{77}$

Albay Deli Halit'in saat 14.30 'da Mudanya'dan gönderdiği raporda: "şiddetli muharebelerden sonra 12 Eylül 1922 saat 13.00 'te 1. Tümen birlikleriyle birlikte

\footnotetext{
${ }^{73}$ Akyol, Bă̆ımsız Yalova Bölüğü, s. 62-63.

${ }^{74}$ Akkılıç, Kurtuluş Savaşında Bursa, s. 616.

${ }^{75}$ Türk İstiklâl Harbi, II cilt, Batı Cephesi, 6. Kısım, III. Kitap, s. 247.

${ }^{76}$ Akyol, Bağımsız Yalova Bölüğ̈̈, s. 64-65.

${ }^{77}$ Türk İstiklâl Harbi, II cilt, Batı Cephesi, 6. Kısım, III. Kitap, s. 255.
} 
Mudanya'ya girildi., ${ }^{, 7}$ bilgilerine yer verilmiştir. Saat 15.00 sularında, 3. Kolordu komutanı Şükrü Naili Paşa ile 1. Tümen komutanı Abdurrahman Nafiz Bey de Mudanya'ya gelmiş, Kocaeli Grubu komutanı Albay Deli Halit ile buluşmuştur. ${ }^{79}$ 3. Kolordu komutanı Şükrü Naili Paşa; durumun daha da kötüye gideceğini düşünmüş, saat 14.30'da Albay Deli Halit'in birliklerinin hemen Mudanya'yı terk etmelerini, 1. Tümen tarafindan esirlerin toparlanıp Bursa'ya sevk edilmesini, kasabada asayişi sağlamaya yetecek birlik bırakılarak Trilye-Eşkel bölgelerine gitmelerini, Mürettep Süvari Tümeni’nin de Runkuç Köprüsü'nü muhafazaya alarak Uluabat doğrultusunda ilerleyip Uluabat Köprüsü'nün işgalini ve su araçlarının emniyete almasını emretmiştir. Bu emrin ardından kendisi de Bursa'ya dönmüştür. ${ }^{80}$

12 Eylül 1922' de, 3. Kolordu kumandanı mirliva Şükrü Naili Paşa, Bursa'nın kurtuluş gününü aşağıdaki ifadelerle anlatılmıştır:

12 Eylül 1922 günü sabahindan itibaren kolordunun yaptı̆̆ taarruz, düşmanin 3 alaylı 11. Fırkasinin esaretiyle nihayet buldu. Bunlardan başka Mudanya'da düşmandan milyonlarca liralk muhabere vesaiti (cephane, erzak, her türlü nakliye vasitasl, otomobil, kamyon, araba, mekkâre, 3 tüp, yüzlerce makineli tüfek, binlerce silah) ganimet olarak ele geçirilmişti. Bu malzemeleri, orduya, esirleri de Bursa'ya hediye ettik. Fakat bununla kolordunun vazifesi bitmiş olmuyordu. Henüz memleket düsmandan tamamen temizlenememişti. Bandırma istikametine kaçan düşman kuvvetlerini de yakalamak veya imha etmek gerekiyordu. Binaenaleyh, bu düşmanı takip için

3. Kolordu 13 Eylül'de bandırma istikametine doğru harekete geçti. ${ }^{81}$

13 Eylül 1922 'de 1. Tümen'in keşifbölüğü, saat 11.15 'te Karacabey'e girmiştir. Keşif Bölüğü’nün Karacabey'de karşılaştığı manzara dehşet vermiş̧i. Kasaba baştan aşağı yakılıp yıkılmıştır. Cadde ve sokaklar insan ölüleriyle dolmuştu. Halkın bir bölümü ise camilere doldurulmuş, ateşe verilip topluca yakılmıştır. ${ }^{82}$

Mürettep Süvari Tümeni'nin Kirmastı yönünde çıkarmış olduğu keşif kolu ise azatlı dolaylarında Yunanlarla iş birliği içindeki eşkıya Davut Çetesi'nin ateşiyle karşılaşmıştı. Bu durum tümene bildirilmiş, keşif koluna destek olarak bir süvari bölüğü gönderilmişti. Kısa süren çatışma sonunda eşkıya Davut çetesi, dağılıp güney kesimdeki dağlara kaçmıştı. ${ }^{83}$ Çetenin dağılması üzerine Yüzbaşı Sabri Bey komutasındaki süvari bölüğü akşam

\footnotetext{
${ }^{78}$ Türk İstiklâl Harbi, II cilt, Batı Cephesi, 6. Kısım, III. Kitap, s. 252.

${ }^{79}$ Akkılıç, Kurtuluş Savaşında Bursa, s. 622-623.

${ }^{80}$ ATASE Arşivi, No: 6/3866, Kls. 2234, Dos. H-11, Fih:4-17, 4-21.

${ }^{81}$ Bursa Salnamesi, s. 61

82 Akkılıç, Kurtuluş Savaşında Bursa, s. 625.

${ }^{83}$ Eşkıya Davut, bu çatışmadan sonra Yunanlara sı̆̆ınıp ülkeyi terk etmiş, daha sonra suç ortaklarıyla birlikte 150'likler listesinde yer almıştı (İbrahim Ethem Akıncı, Demirci Akıncıları, Ankara 1978, s. 383). 150'lilikler Türkiye Cumhuriyeti'nden Kurtuluş Savaşı sonrası sürgün edilen insanlara verilen addır. İçişleri Bakanlığı tarafından oluşturulan ilk hainler listesi 600 kişiden oluşmakta idi. Ancak Lozan Antlaşması'nın bir maddesinde sürgün edilecek insanların sayısının 150'yi geçmeyecek şeklinde öngörmesi üzerine bu liste ilk önce 300 ardından da 149 kişiye indirilmiştir. 150'likler adı verilen ve 23 Nisan 1924 tarihinde Bakanlar Kurulu ve TBMM'nin oturumunda saptanan bu listeye 1 Haziran 1924 tarihindeki kararla “Köylü Gazetesi” sahibi Refet Bey de eklenerek kesin şekliyle 150 kişi olarak kabul edilmiştir (İlhami Soysal, 150’likler, Hür Yayınları, İstanbul 1985, s, 31)
} 
saatlerinde Kirmastı'ya girmişti. Böylece Karacabey ve Kirmastı da Yunan işgalinden kurtarılmıştır. ${ }^{84}$

14 Eylül 1922 günü, sabah 07.00'den itibaren Türk birlikleri ileri harekâta başlamıştır. Albay Deli Halit her zamanki gibi yine en önde olup 18. Tümen'in öncüsünde yer alan birliğiyle beraber hareket etmişti. Saat 15.00 ’te Uluabat Köprüsü başına varılmıştı. Kolordu komutanı Şükrü Naili Paşa da bu sırada Uluabat Köprüsü’nün başına gelip; mürettep süvari tümeni bandırma istikametinde düşmanı sıkıştırıp, Edincik yolunu kapatıp gönen çayı üzerindeki geçitleri elde bulunduracak, Kocaeli Grubu bandırma istikametinde ilerleyecek, 1. Tümen ise Uluabat Köprüsü'nden geçip ileri harekâtını sürdürecek ${ }^{85}$ emrini vermiştir. 14 Eylül 1922 tarihinde, Bursa'yı kurtaran birliklerin komutanı olan Şükrü Naili Paşa'nın verdiği bu emirle, artık Bursa merkezi, bağlı yerleşim yerleri ve civar bölgesinin, Yunan işgalinden kurtarıldığı kesin olarak anlaşılmıştır.

\section{Sonuc}

Mondros mütarekesi sonrasında işgal güçleri, hızla Osmanlı bakiyesinin paylaşılmasına girişmiş̧ir. Padişah ve İstanbul Hükümeti tarafindan kendilerinin taleplerine ve yaptıklarına itiraz veya direniş gösterilmemesi ile birlikte düşüncelerini hoyratça uygulamakta tereddüt göstermemişlerdir. İstanbul Hükümeti'nin yanlarında olması ile uzun yıllarını savaşlarda geçirmiş ve bu defa da yenilgi içerisinde olan Türk milletinin herhangi bir şekilde karşı harekâtta bulunabileceğini düşünmemişlerdir. Böylece kendi planları ve taksimlerine düşen pay doğrultusunda Osmanlı ülkesini karış karış işgal etmişlerdir.

İstanbul Hükümeti'nin; uzlaşı ile hareket edilmesi, direnilmemesi talimatı sonucunda İzmir'in işgal edilmesi, Bursa ve bölgesinin de işgal sürecini başlatmıştır. Milli mücadele başladığında Ankara Hükümeti; Bursa, kasabaları ve civar bölgesini dış cephe niteliği ile düşünüp hareket etmiştir. Bunda İngilizlerin İstanbul ve kendi güvenliklerinin sağlanması için oluşturacakları tampon bölgenin merkezi olarak Bursa'yı belirlemeleri etkili olmuştur. Ayrıca işgali öncesinde Bursa ve bölgesinin Ankara Hükümeti ile yol alıp almayacağı, durumun ne şekilde gelişeceği, uzun bir müddet belirsizliğini korumuştur. İstanbul hükümeti ve işgal güçlerinin, halkı kendi taraflarına çekebilmek için Bursa'ya yönelik girişimlerinin; bir kısım bölge halkı ve şehir yöneticisi tarafindan uygun karşılanması da Ankara Hükümeti'nin Bursa ve bölgesinin işgalinde bir süre kesin tavır alamamasına fikri zemin oluşturmuş̧ur. Tavır belirlenememe sürecinde, başta İngilizler olmak üzere galip devletlerin desteği ve himayesinde ilerleyen Yunan kuvvetleri, 8 Temmuz 1920 tarihinde, Bursa ve civarını işgal etmiş̧tir. Bursa bölgesinde; başlangıçta Türk Milli Mücadelesini destekleyen oluşumların yetersizliği, düzenli bir askerî kuvvetin olmaması, İstanbul Hükümeti ve Yunan işgal güçlerinin müştereken yürüttüğü "bu harekât padişah ve bursa halkına yönelik değil sadece isyancı Mustafa Kemal ve yandaşlarına karşı yapılan bir harekâttır." temelli propagandalar ile Bursa ve Ankara Hükümeti arasında istenen seviyede irtibatın kurulamaması işgalin büyük bir direnişle karşılaşılmadan gerçekleşmesini sağlamıştır. Ankara hükümeti ile Bursa ve civarının ortak hareket edememesi, işgale direnişin zayıflığının memnuniyeti; Yunanların işini kolaylaştırmış ve başlangıçta halka yönelik olumsuz hareketler sergilememelerine zemin hazırlamıştır. İşgalleri esnasında Bursa'da düzenli birlik

\footnotetext{
${ }^{84}$ Akkılıç, Kurtuluş Savaşında Bursa, s. 625.

${ }^{85}$ ATASE Arşivi, No: 6/6083, Kls. 2334, Dos. 5, Fih:108.
} 
olarak karşılarına sadece İzmir'de Yunanlara teslim olan kolordudan kaçabilen, silahıteçhizatı-mühimmatı-personeli dağılmış 56. Tümen unsurlarından oluşan derme-çatma bir askerî birlik çıkabilmiş̧ir.

İşgal sonrası İstanbul Hükümeti’nin işbirlikçi tavırlarının anlaşılması, Ankara Hükümeti ile meclisinin vatanın kurtuluşunda tek umut haline gelmesi, İzmir'de düşmana teslim olan 56. Tümen'in Bursa'da Bekir Sami Bey tarafindan yeniden yapılandırılması, en önemlisi Ankara Hükümeti ile birliktelik sergilenmesinden sonra Bursa ve civarında işgalden kurtulmaya dönük faaliyetlere girişilmiştir. Ankara Hükümeti'nin güçlenmesine bağlı olarak Bursa bölgesinde kurtuluşa gidecek hamleler ve faaliyetler, gizlilik içerisinde, baskılar altında yürütülmeye çalışılmıştır.

Yunanların tamamen yurttan atılıp Kurtuluş Savaşı'nın başarı ile yürümesi aşamasına kadar Ankara Hükümeti ve güçleri tarafindan bu bölgeye yeterli kuvvet ayrılamamıştır. Bursa ve civarında sürdürülen düzenli tüm askerî harekâtlar, Deli Halit Paşa komutasında kurulmuş olan Kocaeli grup komutanlığına bağlı birlikler tarafından yürütülmüştür. Büyük taarruzun başarı ile gelişmesinden ve Türk ordusunun ana kuvvetlerinin İzmir istikametinde düşmanı süpürme harekâtına girişmesinden sonra Şükrü Naili Paşa komutasındaki 3. Kolordu birlikleri, Kocaeli Grubu ile birleştirilebilmiştir. Daha zinde olan 3. Kolordu, Kocaeli Grubu'nu emrine alarak kesin sonuçlu taarruz harekâtına girişmiş ve Bursa ile civarını Yunan işgalinden kurtarmıştır. İncelenen bu askerî harekâtlar neticesinde, Bursa ve civarının savaşılmadan düşman işgaline bırakıldığı ile kurtarıldığı yönündeki olumsuz algıların doğru olmadığı ve imkânsızlıklar içerisinde çok yoğun mücadeleler verildiği görülmüştür. Aynı zamanda Bursa merkezli olarak Marmara bölgesi şeklinde düşünebileceğimiz bu toprakların ve halkın, yeniden ve tereddütsüz olarak Ankara Hükümeti ve milli mücadele harekâtı ile birleştiği de tespit edilmiştir.

Ayrıca, işgalin ilk gününün yıkıcı haberi ile oluşan derin üzüntü içerisinde ara verilen meclis görüşmeleri tekrar başlamış, "puşude-i matem" isimli siyah bir örtü ile kaplanmış olan büyük millet meclisi kürsüsü de aydınlığına kavuşmuştur. Mustafa Kemal'in "ordular! İlk hedefiniz. Akdeniz'dir. İleri!" emriyle Bursa ve civarı, Yunan işgalinden kurtarılmış, Kurtuluş Savaşı'nın tüm cephelerde başarı ile sonuçlandığı Türk milletine ve tüm dünyaya duyurulmuştur. 


\section{Kaynaklar}

Akkılıç, Yılmaz. (1997). Kurtuluş Savaşı'nda Bursa. Bursa: Kültür Sanat Turizm Vakfı Yayınları.

Akkılıç, Yılmaz. (2008). Kurtuluş Savaşı'nda Bursa (İkinci Kitap/İşgalden Kurtuluşa). Bursa: Nilüfer Akkılıç Kütüphanesi Yayınları.

Akyol, Ahmet. (2005). Bir Kahramanlık Destanı Bağımsız Yalova Bölüğ̈̈. Yalova: Diner Ofset.

Aras, Kazım. (1936). İstiklâl Savaşında Kocaeli Bölgesindeki Harekât. İstanbul: Askerî Matbaa.

Artuç, İbrahim. (1985). Büyük Dönemeç Sakarya Meydan Muharebesi. İstanbul: Kastaş Yayınevi.

Batır, Betül. (2017). "Şükrü Naili Paşa Ve Bursa'nın Kurtuluş Günü Hatıratı", AtaTürk Haftası Armağanı Dergisi, Genel Kurmay Personel Başkanlığı, Askerî Tarih Ve Stratejik Etüt (Atase) Daire Başkanlığı Yayını, 44: 67-82

Belen, Fahri. (1962). Büyü̈k Türk Zaferi Afyon'dan İzmir'e: Istiklâl Harbi Hatıralarl, Tenkitler, Tahliller. Ankara: Doğuş Ltd. Şirketi Matbaası.

Beşirli, Mehmet. (2004). "Birinci Dünya Savaşı Öncesinde Türk Ordusunun Top Mühimmatı Alımında Pazar Mücadelesi: Alman Friedrich Krupp Firması Ve Rakipleri”. Selçuk Üniversitesi, Türkiyat Araştırmaları Dergisi, 15, 169-203.

Bursa (Vilayeti) Salnamesi. (1927). Bursa: Feraizcizâde Matbaası.

Dusmanis, Victor. (1928). Küçük Asya Harbi’nin İçyüzü. (Çev. Hristo Ertorun). Atina: Pyrsos Yayın Şirketi Yayınları.

Eğilmez, M. Şükrü (1981). Milli Mücadelede Bursa. (Haz. İhsan Ilgar), İstanbul: Tercüman Tarih Yayınları.

Genelkurmay Askerî Tarih Ve Stratejik Etüt (Atase) Ve Denetleme Başkanlığı Arşivi: No. 5/6534, 6/3866, 6/6083, 4/4478.

Hülagü, Orhan. (2001). Milli Mücadele'de Bursa. İstanbul: Emre Yayınları.

Kutay, Cemal. (1981). Ege'nin Kurtuluşu. İstanbul: Boğaziçi Yayınları.

Özel, Sabahattin. (1987). Kocaeli Ve Sakarya Illerinde Milli Mücadele (1919-1922). İstanbul: Türkiyat Matbaacillkyayınları.

Özkan, İbrahim. (2017). Deli Halit Paşa Unutulan Ylllar (Unutturulan Kahraman). İstanbul: Ötüken Neşriyat.

Sofuoğlu, Adnan. (2003). "Osmanlı Arşiv Belgeleri Işı̆̆ı̀nda Bursa", AtaTürk Araştırma Merkezi, 19(55): 51-82.

Soysal, İlhami. (1985). 150'likler. İstanbul: Hür Yayınları.

Türk İstiklal Harbi. (1969). Il. Cilt Batı Cephesi 6. Kısım 3'ncü Kitap "Büyük Taarruzda Takip Harekâtı (31 Ağustos 18 Eylül 1922)”. Türkiye Cumhuriyeti Genel Kurmay Başkanlığı Yayınları.

Utku, Cumhur Vd. (Haz.). (2011). Kocaeli Burhaniye Kuva-Yı Milliye Müfreze Komutanı Rasim Koçal'ın Milli Mücadele Anıları. Bursa: Akmat Matbaası.

Yüceer, Saime. (2001). Bursa'nın İşgal Ve Kurtuluş Süreci (8temmuz 1920-11 Eylül 1922. Bursa: Uludağ Üniversitesi Yayınları. 


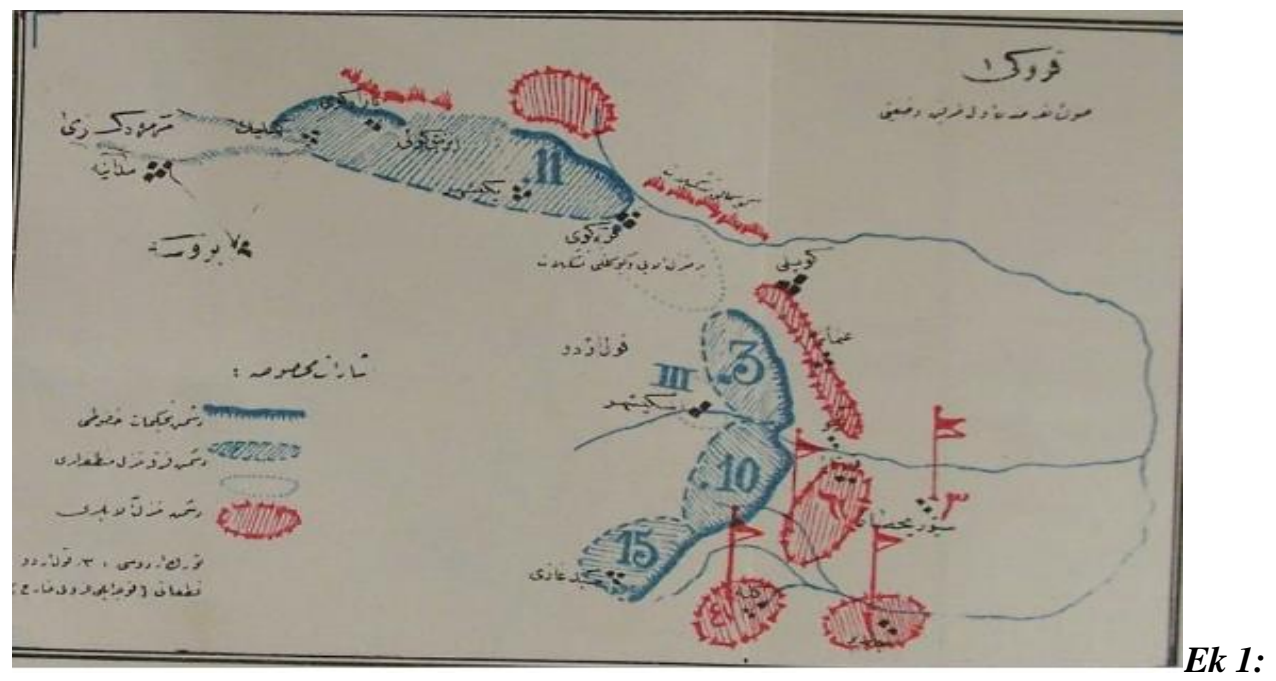

Son Taaruzdan Evvel Tarafeynin (Türk-Yunan) Vaziyetini Gösteren Kroki (Bursa Vilayeti Salnamesi. (1927). Bursa: Feraizcizâde Matbaası, S. 60)

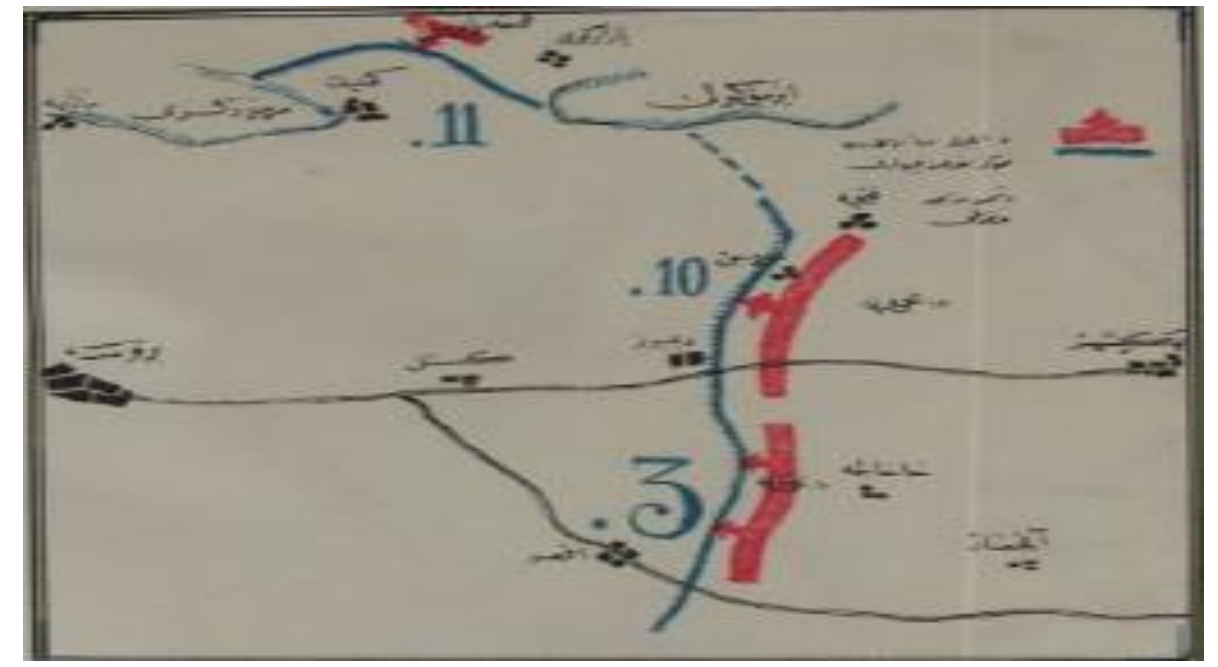

Ek 2: 8 Eylül 1338 (1922) Öğleden Sonra Taarruz Cephelerini Gösteren Kroki (Bursa Vilayeti Salnamesi. (1927). Bursa: Feraizcizâde Matbaası, S. 60) 


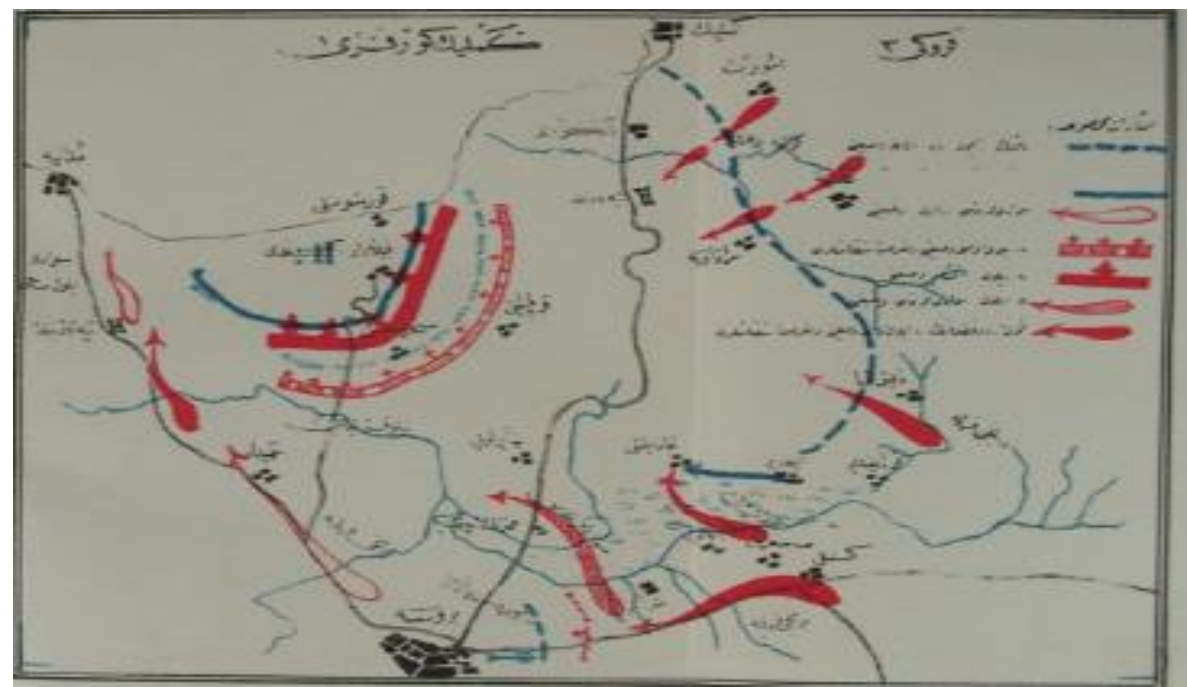

Ek 3: 10-11 Eylül 1338 (1922) Tarihinde Yunan Kuvvetlerinin Yerleşme Plan Ve Taarruz Istikametlerini Gösteren Kroki (Bursa Vilayeti Salnamesi. (1927). Bursa: Feraizcizâde Matbaasl, S. 60) 
